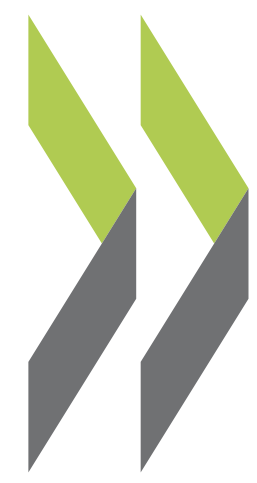

OECD Economics Department Working Papers No. 1434

Urbanisation and household consumption in China

\author{
Margit Molnar, \\ Thomas Chalaux, \\ Qiang Ren
}

https://dx.doi.org/10.1787/d8eef6ad-en 
Organisation de Coopération et de Développement Économiques

Organisation for Economic Co-operation and Development

17-Nov-2017

ECONOMICS DEPARTMENT

English - Or. English

\section{URBANISATION AND HOUSEHOLD CONSUMPTION IN CHINA}

ECONOMICS DEPARTMENT WORKING PAPERS No. 1434

By Margit Molnar, Thomas Chalaux and Qiang Ren

OECD Working Papers should not be reported as representing the official views of the OECD or of its member countries. The opinions expressed and arguments employed are those of the author(s).

Authorised for publication by Alvaro Pereira, Director, Country Studies Branch, Economics Department.

All Economics Department Working Papers are available at www.oecd.org/eco/workingpapers

JT03423206

This document, as well as any data and map included herein, are without prejudice to the status of or sovereignty over any territory, to the delimitation of international frontiers and boundaries and to the name of any territory, city or area. 
OECD Working Papers should not be reported as representing the official views of the OECD or of its member countries. The opinions expressed and arguments employed are those of the author(s).

Working Papers describe preliminary results or research in progress by the author(s) and are published to stimulate discussion on a broad range of issues on which the OECD works.

Comments on Working Papers are welcomed, and may be sent to OECD Economics Department, 2 rue André Pascal, 75775 Paris Cedex 16, France, or by e-mail to eco.contact@oecd.org.

All Economics Department Working Papers are available at www.oecd.org/eco/workingpapers.

This document and any map included herein are without prejudice to the status of or sovereignty over any territory, to the delimitation of international frontiers and boundaries and to the name of any territory, city or area.

The statistical data for Israel are supplied by and under the responsibility of the relevant Israeli authorities. The use of such data by the OECD is without prejudice to the status of the Golan Heights, East Jerusalem and Israeli settlements in the West Bank under the terms of international law.

\section{(c) OECD (2017)}

You can copy, download or print OECD content for your own use, and you can include excerpts from OECD publications, databases and multimedia products in your own documents, presentations, blogs, websites and teaching materials, provided that suitable acknowledgment of OECD as source and copyright owner is given. All requests for commercial use and translation rights should be submitted to rights@oecd.org 


\section{ABSTRACT/RESUMÉ \\ Urbanisation and Household Consumption in China}

This paper focusses on the link between urbanisation and consumption behaviour in China. Urbanisation is defined here as rural people moving to cities to work and migrant workers in cities obtaining urban residential status, against the backdrop of government plans to settle 100 million rural dwellers into cities and grant urban residential status to another 100 million migrant workers who already reside in cities. Using household data of the China Family Panel Studies dataset, the paper investigates the impact of those residential status changes on household consumption. The results of the analysis suggest that moving up the residential ladder in this way will likely result in increased consumption by almost $30 \%$ for both groups of people and thus contribute to rebalancing of the economy. Higher incomes and longer times in education are important drivers of this process, while a greater number of children in the family discourages consumption.

This Working Paper relates to the 2017 OECD Economic Survey of China (www.oecd.org/eco/surveys/economic-survey-china.htm).

Keywords: China, consumption, urbanisation, residential status, migrant workers, rebalancing

JEL: E21, P23, P25, J61

$* * * * * * * * * * * * *$

\section{Urbanisation et Consommation des Ménages en Chine}

Le présent document de travail traite du lien entre urbanisation et comportements de consommation en Chine. L'urbanisation s'entend ici comme l'installation de populations rurales dans des villes et l'obtention, par des travailleurs migrants, du statut de résident urbain, dans un contexte où le gouvernement prévoit d'installer 100 millions de ruraux dans des villes et d'accorder le statut de résident urbain à 100 millions de travailleurs migrants déjà citadins. À partir de données sur les ménages issues de l'enquête " China Family Panel Studies », les auteurs étudient les conséquences de ces évolutions du statut résidentiel sur la consommation des ménages. L'analyse laisse à penser que ces évolutions du statut résidentiel entraîneront probablement une augmentation de la consommation de près de $30 \%$ dans les deux groupes concernés, ce qui contribuera au rééquilibrage de l'économie. La hausse des revenus et de la durée des études jouent un rôle majeur dans ce processus, alors que l'augmentation du nombre d'enfants pèse sur la consommation.

Ce Document de travail se rapporte à l'Étude économique de l'OCDE de la Chine, 2017 (www.oecd.org/fr/eco/etudes/etude-economique-chine.htm).

Mots-clés : Chine, consommation, urbanisation, statut de résident, travailleurs migrants, rééquilibrage

JEL: E21, P23, P25, J61 


\section{TABLE OF CONTENTS}

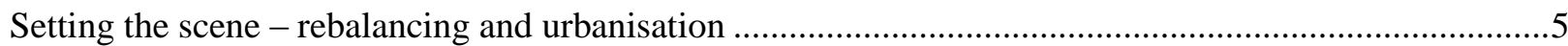

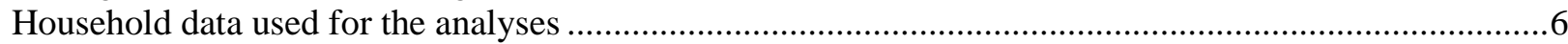

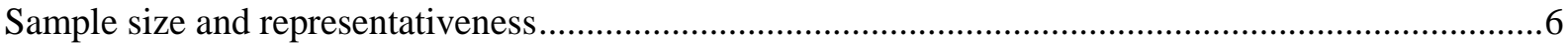

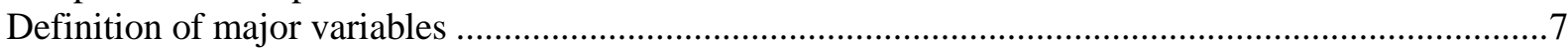

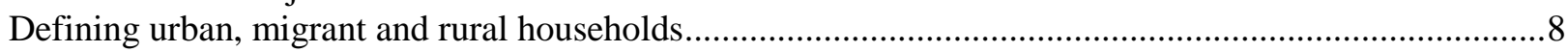

Consumption patterns of urban, migrant and rural households differ ................................................

Distribution of consumption and income of urban, rural and migrant families based on the CFPS ......10

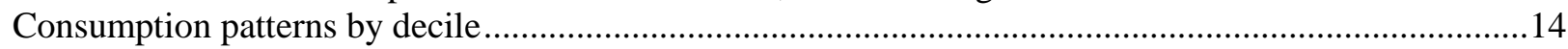

The impact of moving up the "residential ladder" ..................................................................................



How do household features affect spending on various items? ..........................................................20

How do household features affect the spending habits of the different deciles? .....................................21

Wrapping up - inference from micro-data analysis points towards further rebalancing ..........................23

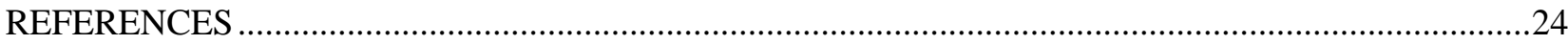

\section{Tables}

Table 1. Consumption patterns of urban, migrant and rural households, 2010, 2012 and 2014...............13

Table 2. Consumption patterns of households by decile, 2014 .........................................................15

Table 3. Changes in households' residential (hukou) status in 2010-12 and 2012-14 ............................16

Table 4. Moving up the residential ladder boosts consumption.............................................................17

Table 5. Higher residential status is associated with higher consumption...............................................19

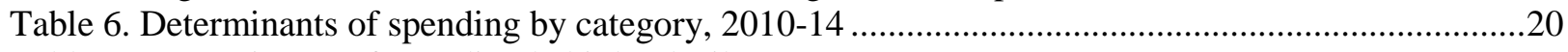

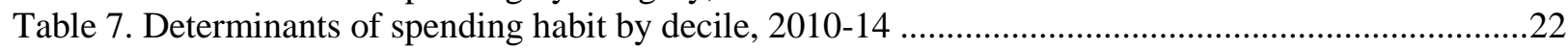

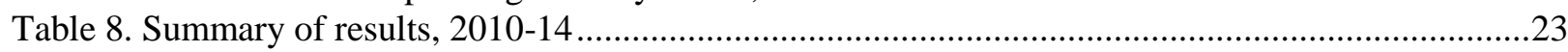

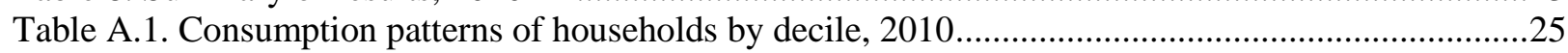

Table A.2. Consumption patterns of households by decile, 2012 …................................................26

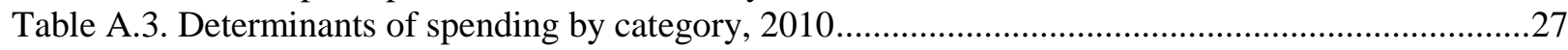

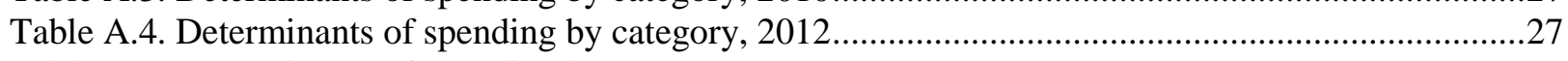

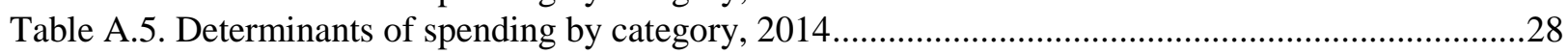

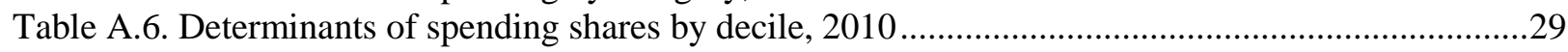

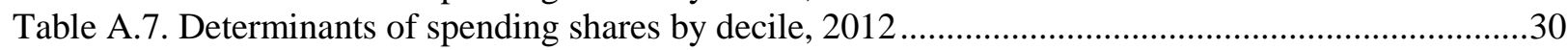

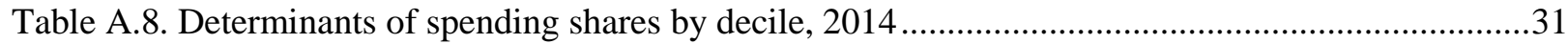

\section{Figures}

Figure 1. Migrants' income and consumption ................................................................................. 10

Figure 2. Rural dwellers increasingly take up jobs in their hometowns, while the number taking

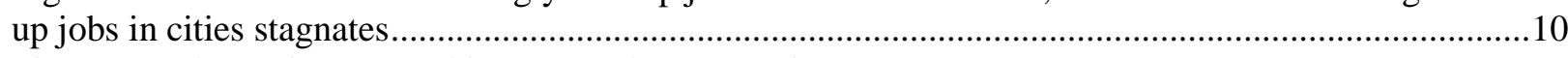

Figure 3. Urban-migrant-rural income and consumption ...................................................................11

Figure 4. Affluent urban households spend almost as little on food as people in Japan and Korea ..........14

\section{Boxes}

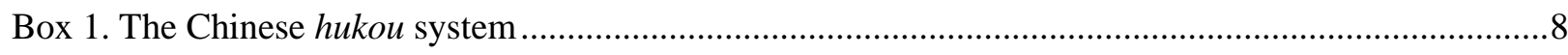




\title{
URBANISATION AND HOUSEHOLD CONSUMPTION IN CHINA
}

\author{
By Margit Molnar, Thomas Chalaux and Qiang Ren ${ }^{1}$
}

\section{Setting the scene - rebalancing and urbanisation}

The Chinese economy is in the process of rebalancing from investment-led to consumption-led growth. So far, this rebalancing has been achieved through slowing investment rather than accelerating consumption. While investment did need to slow, insofar as over-investment led to decreasing investment efficiency, there is ample room for growth to be driven increasingly by consumption.

Indeed, the slow pace of rebalancing towards consumption-led growth is to a large extent attributable to very high household saving (OECD, 2017). Limited social security coverage and the uneven quality of public goods and services provided across the country incentivise people to save for old-age security, for the case of illness or for the education of their offspring. Such saving motives have been strong, though are being reduced by continuing reforms. The introduction of the New Cooperative Medical Scheme, for instance, has contributed to the reduction of saving rates in all but the poorest groups in rural China (Cheung and Padieu, 2014). Nevertheless, since its peak in 2010, the saving rate has fallen by only a couple of percentage points. Government social programmes leave many below the poverty line without any support (Westmore, 2017).

The Chinese government announced plans to continue urbanisation. In terms of the urbanisation rate, China lags behind not only more advanced economies, but also behind some of the other large emerging economies (OECD, 2015). For the 2016-20 13 ${ }^{\text {th }}$ Five Year Plan period, the government envisages (i) 100 million rural residents moving to cities, (ii) extending the provision of public services to another 100 million migrant workers who already live in cities but are excluded from the public services that urban hukou (residence permit) holders benefit from and (iii) improving the living conditions of another 100 million urbanites living in shanty towns. These changes will all contribute to reducing the need for household saving and thus boost consumption.

Drawing on a recent set of household-level data, this paper looks at the consumption patterns of rural, migrant and urban residents and the underlying drivers. Comparing those patterns will allow inferences about the foreseeable impact of the relocation of rural residents and of improving the status and living conditions of the migrants who already live in urban areas. A major contribution of this paper is showing how urbanisation - which is captured as the change in residential status of rural residents into migrants and migrants into urban citizens - affects consumption. While there have been studies such as Dreger et al. (2013) looking at the differences in consumption determinants between urban residents and migrants, to the authors' best knowledge, no empirical study has so far attempted to capture the impact of the change in residential status on consumption.

The paper first introduces the micro-level dataset used for the analysis. It then turns to the consumption patterns of households with different residential status before investigating the potential impact of further urbanisation and the determinants of household consumption of urban, rural and migrant

\footnotetext{
${ }^{1}$ Margit Molnar and Thomas Chalaux are from the OECD's Economics Department and Qiang Ren is Professor at the Centre for Social Research/Institute of Social Science Survey of Peking University. The authors would like to thank Balázs Égert, Ben Westmore and Jean-Marc Fournier from the OECD Economics Department, Rudiger Ahrend from the OECD Centre for Entrepreneurship, SMEs, Local Development and Tourism and participants to an internal seminar discussing the paper for valuable comments on earlier drafts. Special thanks go to Sisse Nielsen, Laura Dockings and Mercedes Burgos, also from the OECD Economics Department, for editorial assistance.
} 
households. The paper also looks at consumption patterns and the underlying factors by consumption decile.

\section{Household data used for the analyses}

The paper uses the China Family Panel Studies (CFPS) survey to provide insights into household consumption. The CFPS survey is a longitudinal one launched in 2010 and conducted by the Institute of Social Science Survey at Peking University. It includes detailed information on respondents' family composition, economic activities, education and living conditions. The structure of the CFPS follows that of the Panel Study of Income Dynamics of the United States, with data collected at five levels: (i) community, (ii) family, (iii) family members, (iv) adults and (v) children in the family (Shen and Lei, 2012).

The survey covers all household members, not only the head or main representative of the household. Family member information is obtained through person-to-person interviews of all adult family members and children above ten, thus the analysis does not need to rely on the main representative or the respondent's data to represent the household (except for information on children below ten, which is obtained primarily from the main caretaker and also from other family members). Instead, household averages are computed per person in a family for the purposes of the analysis in this paper.

The survey defines the household as people living together and/or tied by economic dependency. Family members can be immediate relatives who are economically interdependent or non-immediate relatives who are economically related and have been living in the household for at least three months continuously (Xie and Hu, 2014). The survey tracks members of a family in subsequent waves and around $70 \%$ of the households are retained across waves. The full CFPS survey was undertaken in 2010, 2012, 2014 and 2016, although the last wave is not yet available for analysis.

\section{Sample size and representativeness}

The survey covers 25 provinces or municipalities ${ }^{2}$ (excluding Hainan, Inner Mongolia, Ningxia, Qinghai, Tibet and Xinjiang) that collectively account for $94.5 \%$ of China's total population. It used multistage probability proportional to size sampling with implicit stratification. The three stages for obtaining subsamples include (i) the city district or county, (ii) a neighbourhood community in cities or a village and (iii) the household. The data for those 25 provinces/municipalities are representative of those 25 provinces/municipalities. The sampling strategy ensures that five provinces/municipalities are representative at the province/municipality-level: Shanghai, Liaoning, Henan, Gansu and Guangdong.

A major shortcoming of the CFPS survey is its small sample size relative to China's population size and the number of variables collected. The original plan was to collect data for 16000 households, which was already small, and the size of the sample for which data were actually collected and are suitable for analysis is even smaller. Even though the whole sample matches the age and gender structure of China's overall population, in various dimensions, such as for instance the rural-urban split or the structure of spending, it does not. Considering missing values and the large number of variables that are used in this paper, using the weighted sample would not provide a representative sample. As in this paper a major focus of analysis is the difference between consumption by people with different hukou status, the paper uses the unweighted sample of the 25 provinces/municipalities.

2. The 25 provinces and municipalities include Beijing, Tianjin, Hebei, Henan, Hubei, Hunan, Jiangsu, Jiangxi, Fujian, Guangdong, Guangxi, Guizhou, Yunnan, Sichuan, Chongqing, Gansu, Shaanxi, Shanxi, Shanghai, Anhui, Zhejiang, Shandong, Jilin, Heilongjiang and Liaoning. 


\section{Definition of major variables}

Most basic variables, such as household income or consumption are compiled from the CFPS questionnaire and provided by the Institute of Social Science Survey at Peking University. Compilation involved aggregating the different income and consumption categories obtained directly from the survey. In addition, the Institute also undertook substantial work in filling missing data from available information, checking consistency, extrapolating and interpolating data and making other adjustments based on available information and personal judgment. This may affect the statistical properties or the accuracy of analyses conducted using this dataset.

\section{Household income}

Household income is the sum of salary income, operating income, property income, welfare benefits and other types of income of the household. Salary income of the household was obtained directly from the household-level questionnaire, but if it was missing or zero while the sum of salary income of household members was non-missing and was above zero, it was calculated as the sum of each family member's salary income. Household operating income is the sum of non-salary and business income. The former depends on whether the household is engaged in agricultural production. If so, then their non-salary income is their net income from agricultural production. Business income is calculated from the ownership shares and profit of businesses the family owns.

Property income includes rental income from housing, land, production or other materials. Interest income is supposed to belong to this category, but owing to many missing values, it was not included.

Transfer income includes personal transfer income, presents, government transfers and pensions/severance payments. Personal transfer income is defined as the highest value for support from family and friends among adult members interviewed less caretaking spending by the family. Presents are the cash equivalent of presents received by household members. Government transfers is the sum of transfers received by family members from all government levels. Pension/severance pay is the sum of social security benefits, severance payments, minimum subsistence allowance (dibao) etc. received by family members.

Furthermore, compensation income related, for instance, to land acquisition by the government or capital gains on assets held by the family are not included in household income. The former is not included as it is a result of a decrease in asset holding; the latter is due to purely technical reasons as there was no question on the value of the assets held at the time of their acquisition.

\section{Household consumption}

In the CFPS questionnaire, household consumption covers daily spending items recorded on a monthly basis and special spending items recorded on an annual basis. Altogether ten spending categories are considered as part of household consumption: food, clothing, transportation, communication, education, entertainment, housing (which includes rent, estate management, heating and other utilities), health, and other daily spending/necessities (which include car purchase and maintenance, electric appliances, beauty products and services, lottery and other commercial services). The household-level questionnaire covers all this information. The Institute of Social Science Survey at Peking University grouped education with entertainment/leisure and communication with transport spending, so in the end eight categories are available for analysis.

Spending on purchases of housing or reconstruction/upgrading is highly volatile, therefore is not included. Neither are purchases of commercial insurance and transfers to relatives or others not living together. This latter category comprises different sub-items in different years, for instance taxes and fees 
paid to relevant government departments are included in one year but not in another, therefore is not included in the analysis in this paper.

In contrast to income-related questions, where a relatively large number of people refuse to specify the cash value of presents or personal transfers they receive, the refusal rate for consumption items is very low (Shen and Lei, 2012). For instance, in 2010, only four households refused to reply how much they spend on clothing, one on each of food, transportation and housing. Even so, some people appear not to know how much they spend on food, other daily necessities or transportation.

The CFPS questionnaire did not explicitly ask about the value of self-produced and self-consumed food. The Institute of Social Science Survey at Peking University therefore used the rural part of the 2007 China Household Income Project (CHIP) undertaken by the Institute of China's Income Distribution, Beijing Normal University, the Inter-University Consortium for Political and Social Research and the University of Michigan to correct for that omission. In so doing, they only used the rural part of that survey, as it is mainly rural households who engage in agricultural production.

\section{Defining urban, migrant and rural households}

A major issue for the analysis in this paper is what constitutes an urban, a migrant and a rural household. Following the majority principle, i.e. the household's residential status is defined by the status of the majority of its members, a household is considered urban if the majority of its members reside in urban areas and have a non-agricultural (i.e. urban) hukou (Box 1). A household is considered migrant if the majority of its members reside in urban areas but have a rural/agricultural hukou and rural if the majority of its members live in rural areas and have a rural/agricultural hukou.

\section{Box 1. The Chinese hukou system}

The household registration or hukou system is a specific feature of the Chinese society dating back to ancient times. At present, it is administrated by the local police bureaux and keeps a record of residents in the respective area. Until China's opening up and reforms in the 1980s, the system managed to effectively control population flow from rural to urban areas. Afterwards, rural or so-called migrant workers were instrumental for China's success in becoming the "factory of the world". At the same time, however, the increase of migrants in cities sharpened the contrast with urban citizens who have access to a range of public services linked to their hukou. Those include health and education, thus individual opportunity is determined early in life: being born in urban or rural ares leaves a mark on one's career and life (OECD, 2015). While hukous can be rural and urban (i.e. either agricultural or non-agricultural), the best resources both in terms of healthcare and education are concentrated in the biggest cities. It is therefore not surprising that the relaxation of access rights to public services based on hukou is advancing faster in smaller cities. The conditions are much less restrictive there, while big cities introduced point systems taking into account factors such as the number of years of social security contribution in the city. Granting access to public services to all citizens regardless of hukou is a stated objective for the government.

Source: Various State Council documents.

To define whether an area is urban or rural, the community-level questionnaire of the CFPS survey identifies whether the given community is a village or an urban neighbourhood. At the individual level, each family member's hukou type is identified in the questionnaire.

The above classification of migrant households ignores "urban-urban" migrants, who have an urban hukou but reside in other city than the one of their hukou. This includes migrant workers moving from smaller to larger cities, but also professionals job hopping across large cities. These migrants (who represent around $1-2 \%$ of the total sample) are not the focus of the analysis, nor are "urban-rural" migrants 
(not present in this sample) who typically seek to maintain the right to use the family land when no other siblings living with the elderly parents inherit the land rights. As the focus of this paper is to look at the consumption patterns of urban, migrant and rural workers to infer the potential impact of urbanisation, the exclusion of people with urban hukou living in rural areas (around $2 \%$ of the original sample) is warranted.

The share of migrants in the CFPS Survey is much larger than what NBS surveys revealed: in 2010, around $22 \%$ of households were migrants in the CFPS survey, while the share of rural residents taking up jobs outside their townships was $11 \%$ in the same year according to the NBS (the corresponding figures were $21 \%$ and $12 \%$ in 2012 , and $22 \%$ and $12 \%$ in 2014 , respectively). One reason for the sizeable discrepancy is that those two concepts are not perfectly interchangeable. CFPS surveys the hukou status of all household members, while the NBS focuses on rural residents engaging in non-agricultural work and their questionnaires do not cover dependents of migrants. Furthermore, in the CFPS microdata the share of migrant households is looked at, which is determined based on the majority principle, i.e. if the majority of the household members are migrants, then the household is a migrant household. In contrast, NBS looks at the number of individuals. While a higher share sounds plausible, there is no reference as to how much higher it should be relative to NBS data.

The CFPS is more suitable than other accessible surveys to look at migrants' consumption behaviour. It is not affected by selection bias as it does not only survey migrants, and family members are traced in subsequent waves even if they move away or "migrate" to other places for study, work, marriage or other reasons (Xie and $\mathrm{Hu}, 2015$ ). Therefore, for the purposes of this paper, the CFPS survey is the most appropriate accessible source of information.

\section{Consumption patterns of urban, migrant and rural households differ}

Higher incomes have long attracted rural surplus labour to cities, even though migrants cannot earn as much as urbanites and in most cities until very recently, could not benefit from the same public services and social security. NBS data indicate that migrant incomes have increased steadily over the years (Figure 1), though recently it has become less attractive to migrate to cities. This may partly be attributed to the slowdown of the economy, in particular of manufacturing industries that employ tens of millions of migrant workers. Also, the differential between rural and migrant incomes is narrowing, partly owing to more/better non-agricultural job opportunities in the countryside.

As a result, an increasing number of rural residents take up non-agricultural jobs in their homeplace (township) (Figure 2), without having to move. Consumption data for migrants have only been made available for recent years (Figure 1). The modest increases may be related to increasing migration flows within provinces and decreasing migration flows across provinces to the biggest cities.

While such data are the only public sources of information collected in the NBS migrant surveys, they suffer from an important shortcoming. Surveyors do not interview migrants directly, but collect the information from migrants' household members who remain in the countryside. 236000 migrants' families in 8906 villages of 1527 counties were selected for the survey and the results are considered reliable for the number and the destination of migrant workers. However, the accuracy of such information concerning either incomes or consumption of family members working in faraway cities may be questionable. The NBS has recently started to collect information regarding major variables directly from migrants, though the results are not publicly available. 
Figure 1. Migrants' income and consumption

Per capita

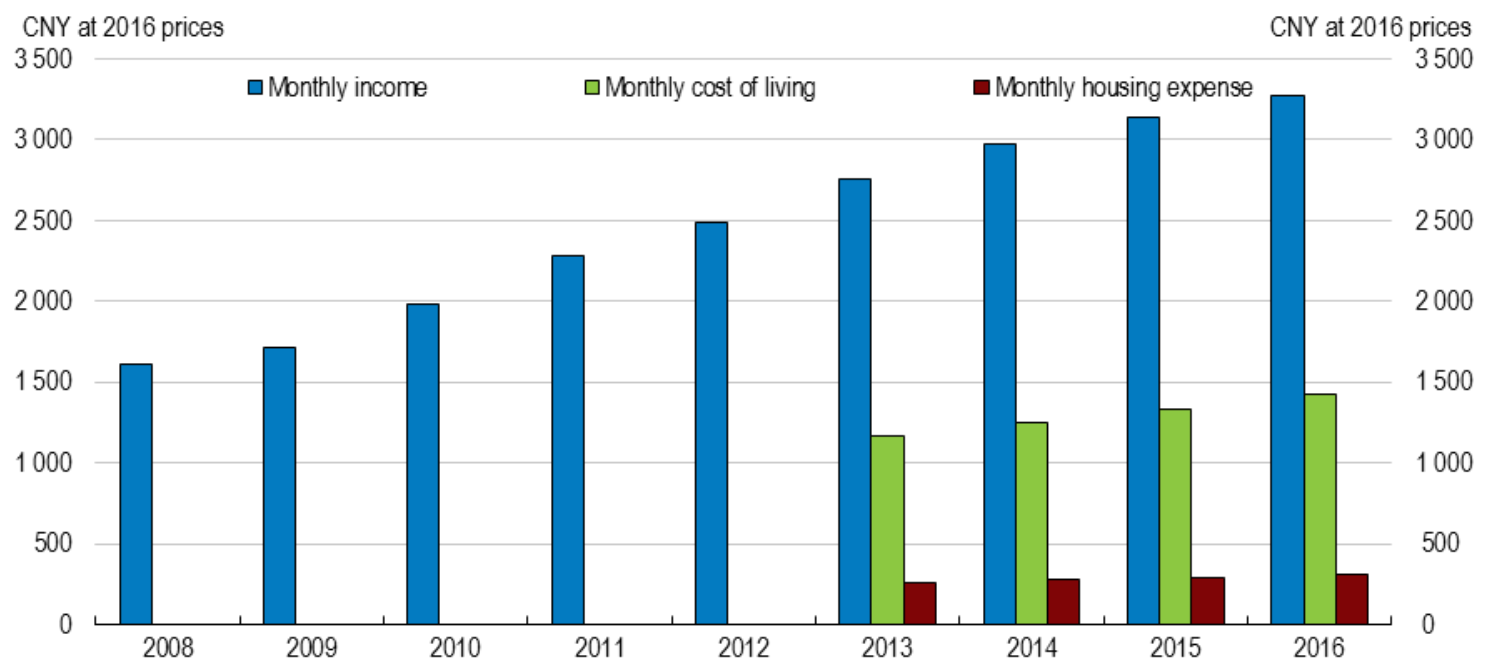

Note: Data cover migrant workers and are based on surveys of their household members remaining in the countryside (if no household members remained, then the village chief). Housing expense is a component of the cost of living.

Source: National Bureau of Statistics.

Figure 2. Rural dwellers increasingly take up jobs in their hometowns, while the number taking up jobs in cities stagnates

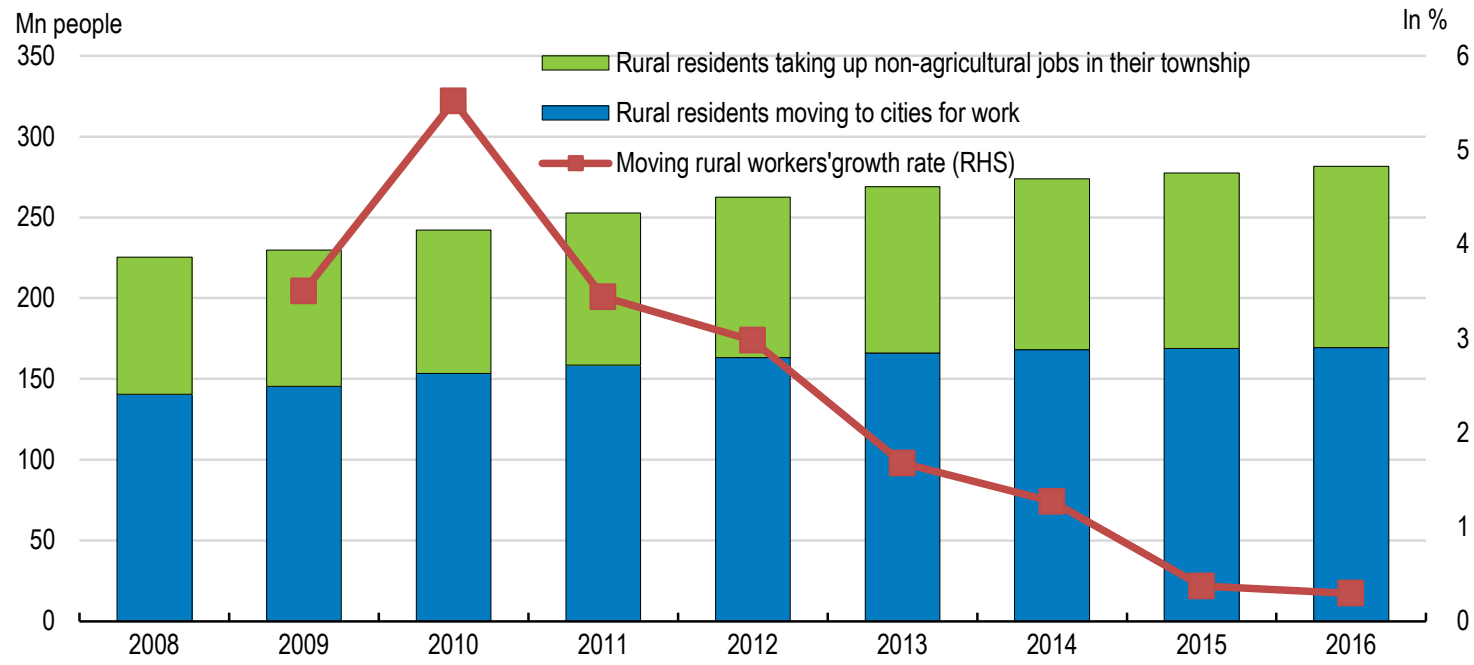

Note: In the general terminology, rural workers (in English often phrased as migrants) refer to both groups in the figure. In this paper, however, migrants only refer to rural people taking up non-agricultural jobs in urban areas as the major interest here is urbanisation.

Source: National Bureau of Statistics.

\section{Distribution of consumption and income of urban, rural and migrant families based on the CFPS}

Looking at the distribution of income and consumption by urban and rural residents as well as migrant workers provides further insights into household consumption by the three groups. The distribution is 
derived using an Epanechnikov kernel function on the unweighted data. While urbanites still had a substantial lead in terms of income in 2014, the differential between rural and migrant workers diminished (Figure 3, Panels A, B and C). On the spending side, the changes are somewhat less striking, even though migrants continue to spend much more than rural residents as the fat tail indicates (Figure 3.F).

Figure 3. Urban-migrant-rural income and consumption

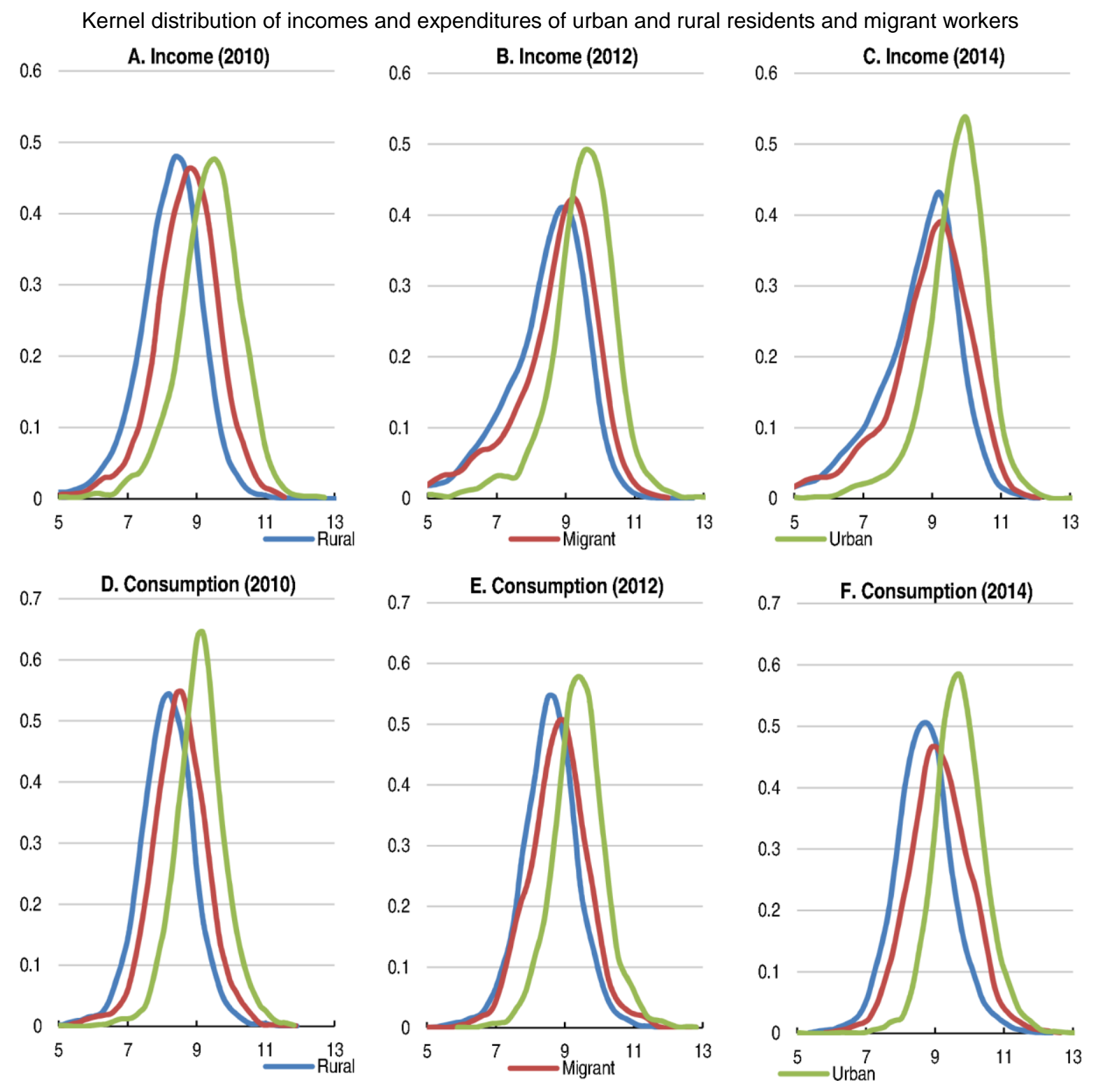

Notes: Household average income and spending in nominal terms. The densities are using an Epanechnikov kernel function on the unweighted data. A household is considered urban if the majority of its members reside in cities and have urban (non-agricultural) hukou, migrant if the majority of the family members reside in cities but have rural (agricultural) hukou and rural if the majority of the members reside in rural areas with a rural (agricultural) hukou. Income and consumption are expressed in logarithm and on a per capita basis.

Source: OECD calculations using the China Family Panel Studies database. 
For urban and migrant workers, the right tail of the consumption distribution thickened over 2010-14 (Figure 3 Panels D, E and F), pointing to the growing size of the group of people with middle-class and above life styles. This phenomenon is more pronounced in the case of migrant workers.

Spending patterns reveal that migrant families spent much more than rural families and urban families much more than migrant families in all the three years, as expected (Table 1). Migrant families were smaller than rural families, but larger than urban ones at 3.9 people on average, compared to 4.4 people in rural and 3.3 in urban families in 2014. Family sizes among urbanites and rural people increased slightly in 2012 relative to 2010 and then remained the same in 2014. In the case of migrants, however, the family size increased from 3.8 in 2010 to 4.1 in 2012 and then decreased to 3.9 in 2014. The fluctuation is attributable to changing number of children, young and old people in the family, which point in different directions. The average ages increased consistently for all the three types of residents, reaching 46.4 for an urban and 41.3 for migrant and 41.9 for rural families in 2014. The age increases are not only attributable to population ageing in China, but also to the fact that the analysis followed the same households, i.e. families in 2010 were also in the dataset in 2012 and likewise those in 2014 were in the database in 2012 (but families in 2014 were not necessarily in the database in 2010). As a rule, at least $70 \%$ of the sample is followed up in the next wave.

The number of years that people spent in education increased for all the three groups over the years, again largely because of the way the sample used for the analysis was constructed. In the original sample, the number of years spent in education for 2014 slightly decreased for rural and urban citizens, which may be related to the fact that the 2014 questionnaire was, to a large extent, conducted through telephone interviews, thus increasing the potential for errors. The old-age dependency ratio increased consistently for all three types of residents over 2010-14. The share of children decreased for all the three groups over 2010-14, while the share of youth in the family decreased for rural and urban people and slightly increased for migrants in 2014. Again, these features are related to the continuity of the households followed in the consecutive waves. 
Table 1. Consumption patterns of urban, migrant and rural households, 2010, 2012 and 2014

Per capita CNY at current prices unless otherwise indicated

\begin{tabular}{|c|c|c|c|c|c|c|c|c|c|c|c|c|}
\hline \multirow[b]{2}{*}{ Status } & \multicolumn{4}{|c|}{2010} & \multicolumn{4}{|c|}{2012} & \multicolumn{4}{|c|}{2014} \\
\hline & Rural & Migrant & Urban & Total & Rural & Migrant & Urban & Total & Rural & Migrant & Urban & Total \\
\hline Income & 5,656 & 8,814 & 17,103 & 9,035 & 7,650 & 10,214 & 19,732 & 11,357 & 9,286 & 12,517 & 23,141 & 13,664 \\
\hline Consumption expenditure & 4,674 & 6,681 & 11,628 & 6,746 & 7,172 & 9,808 & 16,489 & 10,169 & 8,583 & 13,976 & 21,986 & 13,310 \\
\hline Assets & 36,755 & 82,496 & 196,510 & 84,277 & 46,045 & 95,711 & 227,432 & 104,049 & 56,293 & 121,897 & 276,764 & 129,030 \\
\hline \multicolumn{13}{|l|}{ Consumption by items: } \\
\hline Food & 1,691 & 2,408 & 4,313 & 2,464 & 3,061 & 3,797 & 6,146 & 4,025 & 2,716 & 4,772 & 8,617 & 4,728 \\
\hline Healthcare & 777 & 899 & 1,485 & 970 & 868 & 1,036 & 1,436 & 1,052 & 1,094 & 1,352 & 1,980 & 1,385 \\
\hline Clothing & 179 & 309 & 582 & 302 & 332 & 499 & 914 & 520 & 418 & 741 & 1,165 & 686 \\
\hline Housing & 222 & 449 & 875 & 425 & 379 & 661 & 1,197 & 652 & 1,661 & 2,639 & 3,267 & 2,299 \\
\hline Other daily necessities & 489 & 794 & 1,418 & 774 & 1,022 & 1,681 & 2,856 & 1,641 & 1,041 & 2,024 & 2,783 & 1,717 \\
\hline Transport and communication & 547 & 868 & 1,362 & 809 & 561 & 799 & 1,368 & 823 & 808 & 1,189 & 1,647 & 1,113 \\
\hline Education and leisure & 553 & 770 & 1,358 & 789 & 601 & 815 & 1,790 & 958 & 738 & 1,048 & 2,114 & 1,170 \\
\hline Other & 216 & 185 & 235 & 214 & 349 & 521 & 782 & 499 & 108 & 210 & 413 & 211 \\
\hline Family size (number of members) & 4.3 & 3.8 & 3.2 & 3.9 & 4.4 & 4.1 & 3.3 & 4.1 & 4.4 & 3.9 & 3.3 & 4.0 \\
\hline Age (years) & 38.0 & 39.2 & 43.6 & 39.6 & 40.0 & 40.7 & 44.9 & 41.4 & 41.9 & 41.3 & 46.4 & 43.0 \\
\hline Years in education & 6.5 & 7.4 & 9.9 & 7.5 & 7.1 & 7.8 & 10.2 & 8.0 & 7.2 & 8.1 & 10.4 & 8.2 \\
\hline Observations (households) & 4,578 & 1,803 & 1,967 & 8,348 & 4,517 & 1,798 & 2,245 & 8,560 & 4,686 & 1,964 & 2,402 & 9,052 \\
\hline Observations (individuals) & 19,529 & 6,933 & 6,350 & 32,812 & 19,958 & 7,365 & 7,503 & 34,826 & 20,543 & 7,616 & 7,988 & 36,147 \\
\hline Child ratio ( $<16$ / hhd size) & 0.17 & 0.15 & 0.11 & 0.15 & 0.14 & 0.11 & 0.10 & 0.12 & 0.11 & 0.09 & 0.08 & 0.10 \\
\hline Youth ratio (16-25 / hhd size) & 0.15 & 0.14 & 0.10 & 0.14 & 0.14 & 0.14 & 0.09 & 0.13 & 0.13 & 0.15 & 0.08 & 0.12 \\
\hline Old ratio (>64 / hhd size) & 0.10 & 0.10 & 0.15 & 0.11 & 0.12 & 0.12 & 0.17 & 0.13 & 0.15 & 0.13 & 0.19 & 0.15 \\
\hline
\end{tabular}

Notes: A household is considered urban if the majority of its members reside in cities and have urban (non-agricultural) hukou, migrant if the majority of the family members reside in cities but have rural (agricultural) hukou and rural if the majority of the members reside in rural areas with a rural (agricultural) hukou.

Source: OECD calculations using the China Family Panel Studies database. 
Urbanisation brings about changes in consumption patterns. For instance, urbanites tend to spend more on education and leisure. Within urban residents, however, there are large differences: the people in the top decile of the urban expenditure distribution spend much less on $\operatorname{food}^{3}$, displaying a consumption pattern increasingly similar to that of the average household in advanced economies such as Japan or Korea (Figure 4).

Figure 4. Affluent urban households spend almost as little on food as people in Japan and Korea

Share of spending by urban, rural and migrant households, the richest $10 \%$ urban residents in China and average households in Japan and Korea, 2014

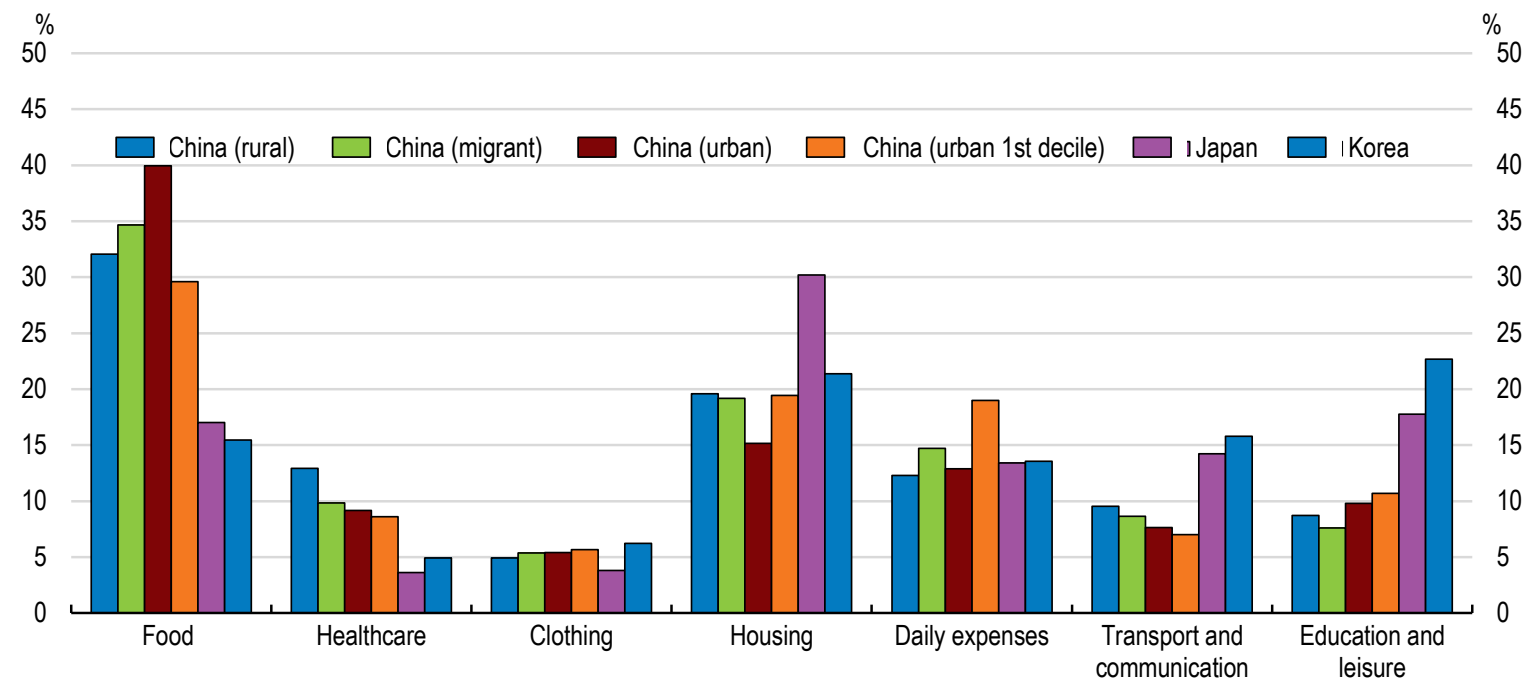

Note: Only categories that are common in the Chinese, Japanese and Korean data are included. The urban first decile corresponds to the top $10 \%$ of urban household in terms of spending.

Source: Authors' calculations based on the China Family Panel Studies database and National Accounts data for Japan and Korea.

\section{Consumption patterns by decile}

Consumption patterns vary not only across residential categories but also across consumption deciles. The lowest spending decile directed half of its spending to food, while the most affluent one only about $28 \%$ (Table A.1) in 2010. This differential narrowed for the bottom decile in 2012, with the former spending around $41 \%$ and the latter still around $28 \%$ on food (Table A.2). In 2014, both edges of the distribution showed changes: the bottom decile directed $38 \%$ and the top decile $25 \%$ of its spending to food (Table 2).

3. This is consistent with Engel's law, which states that as income rises, the share of expenditure on food declines. 
Table 2. Consumption patterns of households by decile, 2014

CNY in current prices unless otherwise indicated

\begin{tabular}{|c|c|c|c|c|c|c|c|c|c|c|c|}
\hline Deciles (2014) & 1 & 2 & 3 & 4 & 5 & 6 & 7 & 8 & 9 & 10 & Total \\
\hline Income & 5,617 & 6,544 & 7,840 & 8,389 & 9,649 & 11,446 & 13,949 & 16,982 & 21,901 & 34,334 & 13,664 \\
\hline Consumption expenditure & 1,822 & 3,341 & 4,633 & 6,018 & 7,628 & 9,532 & 12,093 & 15,925 & 22,544 & 49,579 & 13,310 \\
\hline Assets & 32,226 & 40,439 & 54,989 & 60,451 & 76,291 & 92,682 & 126,167 & 167,583 & 228,589 & 411,053 & 129,030 \\
\hline \multicolumn{12}{|l|}{ Consumption by items: } \\
\hline Food & 697 & 1,335 & 1,877 & 2,462 & 3,243 & 3,973 & 5,270 & 6,957 & 9,006 & 12,464 & 4,728 \\
\hline Healthcare & 258 & 420 & 550 & 700 & 747 & 1,069 & 1,229 & 1,464 & 2,846 & 4,569 & 1,385 \\
\hline Clothing & 129 & 215 & 295 & 357 & 453 & 488 & 621 & 811 & 1,135 & 2,361 & 686 \\
\hline Housing & 244 & 405 & 556 & 771 & 950 & 1,200 & 1,592 & 2,251 & 3,093 & 11,935 & 2,299 \\
\hline Other daily expenses & 141 & 274 & 400 & 472 & 596 & 818 & 985 & 1,392 & 2,289 & 9,802 & 1,717 \\
\hline Transport and communication & 226 & 389 & 513 & 635 & 792 & 903 & 1,146 & 1,419 & 1,904 & 3,209 & 1,113 \\
\hline Education and leisure & 107 & 262 & 391 & 552 & 754 & 969 & 1,100 & 1,414 & 1,889 & 4,267 & 1,170 \\
\hline Other & 21 & 39 & 51 & 69 & 94 & 112 & 151 & 217 & 382 & 972 & 211 \\
\hline $\begin{array}{l}\text { Family size (number of } \\
\text { persons) }\end{array}$ & 5.0 & 4.5 & 4.5 & 4.4 & 4.2 & 4.0 & 3.7 & 3.6 & 3.1 & 3.0 & 4.0 \\
\hline Age (years) & 44.1 & 43.6 & 42.6 & 42.2 & 41.8 & 43.1 & 42.4 & 42.7 & 44.6 & 42.7 & 43.0 \\
\hline Years in education & 6.6 & 6.9 & 7.1 & 7.4 & 7.8 & 8.1 & 8.7 & 9.2 & 9.7 & 10.8 & 8.2 \\
\hline Child ratio (<16 / hhd size) & 0.11 & 0.11 & 0.12 & 0.12 & 0.11 & 0.10 & 0.10 & 0.09 & 0.07 & 0.06 & 0.10 \\
\hline Youth ratio (16-25 / hhd size) & 0.11 & 0.11 & 0.11 & 0.12 & 0.13 & 0.12 & 0.12 & 0.12 & 0.13 & 0.13 & 0.12 \\
\hline Old ratio (>64 / hhd size) & 0.19 & 0.17 & 0.15 & 0.15 & 0.12 & 0.15 & 0.14 & 0.15 & 0.19 & 0.13 & 0.15 \\
\hline \multicolumn{12}{|l|}{ Share of consumption: } \\
\hline Food & 38.3 & 40.0 & 40.5 & 40.9 & 42.5 & 41.7 & 43.6 & 43.7 & 39.9 & 25.1 & 35.5 \\
\hline Healthcare & 14.1 & 12.6 & 11.9 & 11.6 & 9.8 & 11.2 & 10.2 & 9.2 & 12.6 & 9.2 & 10.4 \\
\hline Clothing & 7.1 & 6.4 & 6.4 & 5.9 & 5.9 & 5.1 & 5.1 & 5.1 & 5.0 & 4.8 & 5.2 \\
\hline Housing & 13.4 & 12.1 & 12.0 & 12.8 & 12.5 & 12.6 & 13.2 & 14.1 & 13.7 & 24.1 & 17.3 \\
\hline Other daily expenses & 7.7 & 8.2 & 8.6 & 7.8 & 7.8 & 8.6 & 8.1 & 8.7 & 10.2 & 19.8 & 12.9 \\
\hline Transport and communication & 12.4 & 11.6 & 11.1 & 10.6 & 10.4 & 9.5 & 9.5 & 8.9 & 8.4 & 6.5 & 8.4 \\
\hline Education and leisure & 5.9 & 7.8 & 8.4 & 9.2 & 9.9 & 10.2 & 9.1 & 8.9 & 8.4 & 8.6 & 8.8 \\
\hline Other & 1.1 & 1.2 & 1.1 & 1.1 & 1.2 & 1.2 & 1.3 & 1.4 & 1.7 & 2.0 & 1.6 \\
\hline
\end{tabular}

Source: OECD calculations using the China Family Panel Studies database. 


\section{The impact of moving up the "residential ladder"}

The best way to look at the impact of rural people moving to cities and of "urbanising" migrant workers who are already in cities is to look at how the consumption behaviour of those people who move up this "residential ladder" between 2010 and 2014 changes. Based on a panel of 2010, 2012 and 2014 data, roughly 229 rural households, who lived in the countryside in 2010, migrated to cities to work by 2012 (Table 3), while keeping their rural hukou. During the same period, 286 migrant families obtained an urban hukou. The corresponding numbers for households moving up the residential ladder over 2012-14 are 106 and 115 , respectively (Table 3 ).

Table 3. Changes in households' residential (hukou) status in 2010-12 and 2012-14

\begin{tabular}{|l|ccc|}
\hline 2010/2012 & Rural & Migrant & Urban \\
\hline Rural & 4,752 & 229 & 7 \\
Migrant & 32 & 1,650 & 286 \\
Urban & 0 & 58 & 2,038 \\
\hline
\end{tabular}

\begin{tabular}{|l|ccc|}
\hline $2012 / 2014$ & Rural & Migrant & Urban \\
\hline Rural & 4,656 & 106 & 22 \\
Migrant & 30 & 1,792 & 115 \\
Urban & 0 & 66 & 2,265 \\
\hline
\end{tabular}

Note: A household is considered urban if the majority of its members reside in cities and have urban (non-agricultural) hukou, migrant if the majority of the family members resides in cities but have a rural (agricultural) hukou and rural if the majority of the members reside in rural areas with a rural (agricultural) hukou.

Source: OECD calculations using the China Family Panel Studies database.

While there have been other types of changes in household hukou, these two types count as "moving up the residential ladder" and are targeted by government plans, making the change in their consumption behaviour the focus of this paper.

To examine how the change in residential status affects consumption, first the dummies for different types of households were defined. Separate dummies were constructed for households not changing their status, be it urban, rural or migrant, respectively. Also a set of dummies were constructed for those households who changed their status from rural to migrant or migrant to urban. Then the change of consumption in 2012 relative to 2010 and in 2014 relative to 2012 (and income and assets in a separate regression) was regressed on those dummies. The change of income over that period was included as a control variable. The results indicate that moving from rural to migrant status substantially raises spending (and income) (Table 4). "Upgrading" from migrant to urban status also boosts spending by a third (though income only increased by $16 \%$ ). While these coefficients are statistically significant at the $1 \%$ level and appear with the expected signs, they should be interpreted with care. Due to the small original sample size, the results cannot be considered representative. Nevertheless they indicate that moving up the "residential ladder" may boost consumption and therefore contribute to rebalancing the economy. 
Table 4. Moving up the "residential ladder" boosts consumption

Regression coefficients of spending/income/assets change on residential status change dummies, 2010-14

\begin{tabular}{|l|ccc|}
\hline 2010-14 & Income & Consumption & Assets \\
\hline Income & & $0.07^{* * *}$ & $0.10^{* * *}$ \\
Rural-rural & $0.16^{* * *}$ & $0.24^{* * *}$ & $0.22^{* * *}$ \\
Rural-migrant & $0.40^{* * *}$ & $0.28^{* * *}$ & -0.02 \\
Migrant-migrant & 0.03 & $0.31^{* * *}$ & $0.29^{* * *}$ \\
Migrant-urban & $0.17^{* *}$ & $0.27^{* * *}$ & $0.28^{* * *}$ \\
Urban-urban & $0.17^{* * *}$ & $0.28^{* * *}$ & $0.24^{* * *}$ \\
\hline R2 & 0.01 & 0.10 & 0.05 \\
Observations & 16,846 & 16,846 & 16,846 \\
\hline
\end{tabular}

Note: * indicate p values, ${ }^{*}$ significance at the $10 \%,{ }^{* *}$ at the $5 \%$ and ${ }^{* * *}$ at the $1 \%$ level. Income, consumption and assets data are (changes in) household average income, consumption and assets in nominal terms. Even accounting for the roughly $6 \%$ average $\mathrm{CPI}$ inflation over 2010-12 and 2012-14, rural households would have a 10\% real income growth. A household is considered urban if the majority of its members reside in cities and have urban (non-agricultural) hukou, migrant if the majority of the family members reside in cities but have rural (agricultural) hukou and rural if the majority of the members reside in rural areas with a rural (agricultural) hukou. Changes in income, consumption and assets are in log differences and on a per capita basis. In the consumption and assets equations, change in income is included as a control variable.

Source: OECD estimations using the China Family Panel Studies database.

\section{What household features affect consumption?}

To examine the major drivers of household consumption, it was regressed on basic household features using the 2010, 2012 and 2014 samples separately and on the pooled 2010-12-14 dataset (Table 5). The explanatory variables include average income, average household age, average years of education, the share of small children (below 16) and youth (16-25) as well as elderly people (above 65) in the family. Consumption, income, age and years of education are expressed on a per capita basis and consumption and income are in logarithms. In addition, dummies indicating residential status are also included. The rural status dummy is used as a base for comparison and therefore dropped. The cross-section regressions only allow inferring about correlations between consumption and the explanatory variables, not establishing causal relationships. The pooled regression in the last column in turn allows exploiting also the time dimension of the data and includes year dummies. For estimation, the ordinary least squares (OLS) estimator is used with robust standard errors clustered at the province level.

Most variables appear with the right sign and most are statistically significant at the $1 \%$ level. A unit increase in income is associated with a fifth-of-a-unit increase in consumption. The small size of the coefficient indicates that an increase in incomes alone would only lead to slow rebalancing. The size of the coefficient is not very different from the one estimated by Nicklaus (2015) at 0.27 using the China Household Finance Survey's 2011 wave, which included 8438 households. Estimates for earlier years, however, show much higher coefficients: for instance, Dreger at al. (2013) estimated 0.77 for urban and 0.83 for migrant households in 2007 using the China Household Income Project (CHIP) dataset's 2002 and 2007 wave including 10000 households in the latter year. The settings in those studies, however, are not exactly the same as in this paper, therefore the results are also not directly comparable. For instance, those studies do not control for the share of children, youth and old in the family as this paper does. 
On average, the more educated family members are (captured by the average number of years spent in education), the more they consume. Even though the coefficient is small, increased education can be another driver of rebalancing. This is in line with the findings of Nicklaus (2015), where the size of the estimated coefficient increases with higher education levels.

The share of young children or youth in the family, in contrast, is negatively associated with consumption (in the regressions variables are on a per capita basis). This may be explained by saving to send children to expensive preparatory courses to try to enrol in good schools (Croll, 2006).

Age (measured by the average age of household members) does not appear to have a statistically significant association with consumption, neither in the pooled, nor in the cross-section regressions. In contrast, older people tend to hold more assets, which is explained by the longer time they have had to accumulate them. Nicklaus (2015) found a statistically significant negative coefficient on the age variable, though he did not control for the age composition of the household as this paper did by including the kids, teens and olds ratios.

The coefficients for both the migrant and urban dummies are positive and statistically significant at the $1 \%$ level, indicating that both groups spend more (and have higher incomes) than rural residents (the dummy for which is dropped and is used as a base to compare the other two groups). The coefficients are relatively large as migrants and urban citizens tend to consume more even after controlling for income and family characteristics. The coefficient on the urban dummy at 0.5 in the stacked regression including 2010 , 2012 and 2014 data, for instance, seems much higher than the 0.33 estimated by Nicklaus (2015) for 2011, but the one in 2010 at 0.36 is very close. Dreger et al. (2013) showed that the average propensity to consume is 5-6 percentage points higher for urban hukou holders relative to migrants at similar income levels and controlling for socio-demographic characteristics. They used the 2002 and 2007 waves of the CHIP survey. As above, the results are not directly comparable due to different model settings.

The coefficients for the 2012 and 2014 dummies are positive and statistically significant and relatively large, with the exception of the coefficient on the 2012 dummy in the income equation. As time passes, people tend to consume more. This may be related to the availability of an increasing choice of goods and services every year to consume and the improving environment for consumption, for instance the proliferation of e-commerce and mobile payment services. 
Table 5. "Higher" residential status is associated with higher consumption

\begin{tabular}{|c|c|c|c|c|c|c|c|c|c|c|c|c|}
\hline & \multicolumn{3}{|c|}{2010} & \multicolumn{3}{|c|}{2012} & \multicolumn{3}{|c|}{2014} & \multicolumn{3}{|c|}{ 2010-14 } \\
\hline & Income & Consumption & Assets & Income & Consumption & Assets & Income & Consumption & Assets & Income & Consumption & Assets \\
\hline Income & & $0.34^{* * *}$ & & & $0.13^{* * *}$ & & & 0.19 *** & & & 0.20 *** & \\
\hline \multicolumn{13}{|l|}{ Status } \\
\hline Migrant & $0.31^{* * *}$ & $0.15^{* * *}$ & $0.44^{* * *}$ & $0.13^{* *}$ & $0.17^{* * *}$ & $0.43^{* * *}$ & 0.12 & $0.34^{* * *}$ & $0.43^{* * *}$ & $0.19^{* * *}$ & $0.24^{* * *}$ & $0.44^{* * *}$ \\
\hline Urban & $0.62 * * *$ & 0.36 *** & $0.62 * * *$ & $0.66^{* * *}$ & $0.47^{* * *}$ & $0.68^{* * *}$ & $0.70 * * *$ & $0.59 * * *$ & $0.74 * * *$ & $0.66^{* * *}$ & $0.50 * * *$ & $0.69 * * *$ \\
\hline Kids ratio & $-0.92^{* * *}$ & $-0.41^{* * *}$ & -0.22 & $-0.61^{* * *}$ & -0.07 & 0.06 & $-0.43^{* * *}$ & 0.03 & 0.38 & $-0.59 * * *$ & $-0.18^{* * *}$ & 0.03 \\
\hline Teens ratio & $-0.62 * * *$ & -0.20 ** & -0.49 ** & -0.20 & -0.19 *** & $-0.57^{* * *}$ & -0.04 & 0.02 & -0.56 *** & $-0.24^{* * *}$ & $-0.12^{* *}$ & $-0.53^{* * *}$ \\
\hline Olds ratio & -0.26 ** & 0.01 & $-0.69 * * *$ & $-0.24^{* * *}$ & -0.05 & $-0.43^{* * *}$ & -0.22 *** & $0.11^{* *}$ & $-0.64^{* * *}$ & $-0.25^{* * *}$ & 0.01 & $-0.60^{* * *}$ \\
\hline Age & -0.00 & 0.00 & $0.02^{* * *}$ & -0.00 & 0.00 & $0.02^{* * *}$ & 0.00 & -0.00 & 0.02 *** & 0.00 & 0.00 & $0.02^{* * *}$ \\
\hline Education & $0.13^{* * *}$ & $0.05^{* * *}$ & $0.15^{* * *}$ & $0.13^{* * *}$ & $0.07^{* * *}$ & $0.16^{* * *}$ & $0.12^{* * *}$ & $0.07^{* * *}$ & $0.14^{* * *}$ & $0.13^{\star \star *}$ & 0.06 *** & $0.15^{* * *}$ \\
\hline \multicolumn{13}{|l|}{ Dummies year } \\
\hline 2012 & & & & & & & & & & 0.02 & $0.31^{* * *}$ & $0.23^{* * *}$ \\
\hline 2014 & & & & & & & & & & $0.19^{* \star *}$ & $0.47^{* * *}$ & $0.34^{* * *}$ \\
\hline Constant & 7.69 *** & $5.06^{* * *}$ & 8.30 *** & $7.67^{* \star *}$ & $6.95^{* \star *}$ & $8.58^{* * *}$ & $7.69^{* * *}$ & $6.56^{* * *}$ & $8.76^{* * *}$ & $7.56^{\star \star *}$ & $6.07^{* * *}$ & $8.37^{* * *}$ \\
\hline $\mathrm{R} 2$ & 0.29 & 0.40 & 0.18 & 0.19 & 0.24 & 0.24 & 0.20 & 0.33 & 0.19 & 0.23 & 0.36 & 0.22 \\
\hline Observations & 8,348 & 8,348 & 8,348 & 8,522 & 8,522 & 8,522 & 9,052 & 9,052 & 9,052 & 25,922 & 25,922 & 25,922 \\
\hline
\end{tabular}

Note: Income, consumption and assets are in logarithms and on a per capita basis. OLS is used with year and residential status dummies with robust standard errors clustered at the province level. * indicate $p$ values, ${ }^{*}$ significance at the $10 \%,{ }^{* *}$ at the $5 \%$ and ${ }^{* * *}$ at the $1 \%$ level. A household is considered urban if the majority of its members reside in cities and have urban (non-agricultural) hukou, migrant if the majority of the family members reside in cities but have rural (agricultural) hukou and rural if the majority of the members reside in rural areas with a rural (agricultural) hukou.

Source: OECD estimations using the China Family Panel Studies database. 


\section{How do household features affect spending on various items?}

To get further insights into the consumption of the various groups, spending on selected consumption items was examined. More specifically, spending on various consumption categories (one at a time) was regressed on a number of household features using the 2010, 2012 and 2014 datasets separately and the stacked 2010-12-14 dataset (Tables A3-A5). As above, those features include average income, average household age, average years of education, the share of small children (below 16) and youth (16-25) as well as elderly people (above 65 ) in the family and dummies indicating residential status.

Older households tend to spend less on transport and communication and other daily necessities and more on food and healthcare, with coefficients significant at the 1\% level in the stacked 2010-12-14 data analysis (Table 6). The coefficients on the age variable, however, are very small in all equations.

Table 6. Determinants of spending by category, 2010-14

\begin{tabular}{|c|c|c|c|c|c|}
\hline $\begin{array}{l}\text { As a share of total } \\
\text { consumption expenditure }\end{array}$ & Food & Healthcare & $\begin{array}{l}\text { Education and } \\
\text { leisure }\end{array}$ & $\begin{array}{l}\text { Transport and } \\
\text { communication }\end{array}$ & $\begin{array}{l}\text { Other daily } \\
\text { expenses }\end{array}$ \\
\hline \multicolumn{6}{|l|}{ Status } \\
\hline Migrant & $0.01^{* *}$ & $-0.01^{* * *}$ & $-0.01^{* *}$ & -0.00 * & 0.00 \\
\hline Urban & $0.05^{* * *}$ & $-0.02^{* * *}$ & $-0.01^{* \star *}$ & $-0.01^{* * *}$ & -0.01 ** \\
\hline Child ratio & 0.03 & $-0.04 * * *$ & $0.18^{* * *}$ & $-0.08 * * *$ & $-0.04 * * *$ \\
\hline Youth ratio & $-0.05^{*}$ & $-0.04^{* * *}$ & $0.22^{* * *}$ & $-0.03^{* * *}$ & $-0.05^{* * *}$ \\
\hline Olds ratio & -0.02 ** & $0.05^{* * *}$ & -0.01 & $-0.02^{* * *}$ & -0.00 \\
\hline Age & $0.00^{* * *}$ & $0.00^{* * *}$ & 0.00 & $-0.00 * * *$ & $-0.00^{* * *}$ \\
\hline Education & $-0.01^{* * *}$ & $-0.01^{* * *}$ & $0.01^{* * *}$ & $0.00^{* * *}$ & $0.00^{* * *}$ \\
\hline \multicolumn{6}{|l|}{ Dummies year } \\
\hline 2012 & $0.03^{* * *}$ & $-0.03^{* * *}$ & $-0.01^{* * *}$ & $-0.03^{* * *}$ & $-0.01 * *$ \\
\hline 2014 & -0.01 * & $-0.03 * * *$ & -0.01 & $-0.02 * * *$ & $-0.02 * * *$ \\
\hline Constant & $0.42^{* * *}$ & $0.15^{* * *}$ & $-0.05^{* *}$ & $0.18^{* * *}$ & $0.14^{* * *}$ \\
\hline $\mathrm{R} 2$ & 0.05 & 0.08 & 0.12 & 0.06 & 0.02 \\
\hline Observations & 25,922 & 25,922 & 25,922 & 25,922 & 25,922 \\
\hline
\end{tabular}

Note: Income, consumption and assets are in logarithms and on a per capita basis. OLS is used with year and residential status dummies with robust standard errors clustered at the province level. * indicate p values, * significance at the $10 \%,{ }^{* *}$ at the $5 \%$ and ${ }^{* * *}$ at the $1 \%$ level. A household is considered urban if the majority of its members reside in cities and have urban (non-agricultural) hukou, migrant if the majority of the family members reside in cities but have rural (agricultural) hukou and rural if the majority of the members reside in rural areas with a rural (agricultural) hukou.

Source: OECD estimations using the China Family Panel Studies database.

More educated people spend more on education and leisure, transport and communications and other daily necessities, though less on food and healthcare. Although the coefficients on the education variable (the average number of years of education of household members) are significant at the $1 \%$ level in these three regressions, the size of the coefficients is very small, indicating only a very limited impact of education on consumption in those categories.

Families with a higher share of smaller children spend more on education and leisure and healthcare and less on transport and communications and other daily necessities. A greater share of youth in the family also leads to lower spending on these latter three categories (as well as food), and higher spending on education and leisure. A greater share of older people in the family reduces spending on food and transport and communications, but increases spending on healthcare. These results may be related to a more frequent need for healthcare services and less need for regular commuting (for instance to work) at an older age.

Urban residents tend to direct a lower share of their consumption spending to healthcare, education and leisure, transport and communications and other daily necessities than rural ones indicating both a 
more developed and generous social security system and still much higher incomes in cities. In contrast, a greater share goes to food, likely because more options are available for eating out and delivery services and there is a greater choice of food items in shops in urban areas.

Migrants tend to direct a lower share of their consumption spending to healthcare, education and leisure, and transport and communications than rural residents, indicating higher incomes and more and better availability of public goods and services in cities compared to the countryside. Just like urban residents, migrants also spend a greater share on food as in cities there are more options and they earn higher wages.

\section{How do household features affect the spending habits of the different deciles?}

To get further insights into household consumption, the paper examined the determinants of spending in the selected categories by decile. Here the household deciles are defined for the consumption variable. As above, cross-section analyses were conducted using the 2010, 2012 and 2014 data separately, followed by analyses of the stacked dataset of 2010-12-14 (Tables 7 and A.6.-A.8). The lowest-spending group serves as a base for comparison for the other deciles and is therefore dropped.

The results of the stacked 2010-12-14 analyses show that being in the lower-spending deciles boosts spending on food relative to the lowest decile, though when moving up the deciles, the coefficient loses significance, switches sign and for the most affluent decile it turns negative. While it is clear why the highest-spending decile spends a lower share on food than the lowest decile, as they may spend more on other, more pricey but not vital activities such as leisure, sports or travel, the observation that from the second to the $7^{\text {th }}$ decile people spend a greater share on food than the lowest decile may indicate that food can be a major driver of spending as people can afford to spend more. Gale and Huang (2007) found earlier that top-earning households reached a point where the income elasticity of demand for quantity of most foods is near zero. Higher earners instead purchase more expensive foods, which has led to an increasingly segmented food market.

In all deciles (except the first one), people spend more on education and leisure than the first decile. In contrast, people spend less on transport and communication than the lowest decile in all other deciles. These seemingly puzzling opposite signs on the coefficients may be related to the standard types of services like transport and communication on the one hand and highly differentiable goods and services such as food, education and leisure on the other. When people spend a greater share of their overall consumption on food, education or leisure, they do not necessarily buy more of those goods and services, but more likely higher quality, which costs more. Indeed, in the retail food sector, it has been mainly the richer households that have been the major driver of demand (Gale and Huang, 2007). In addition to food, education and leisure also tend to be major drivers of consumption spending. There are relatively fewer options to spend more on transport and communication by purchasing better quality services. Buying a car, for instance, would not be categorised in the CFPS survey as consumption-type spending and the price difference between transportation options in most cases is smaller than between catering outlets, education services or leisure facilities.

Higher incomes do not appear to have a big impact on the demand for healthcare services. Only the highest two deciles spend a significantly greater share on healthcare than the lowest decile. This may be explained by consumption of different quality of goods and services by the most affluent people, for instance buying imported goods or receiving healthcare treatment abroad. Zhou et al. (2011) find a greater income elasticity of demand for reimbursed services than for uninsured services in rural China where the New Cooperative Medical Scheme, which is a partial insurance, was introduced in 2004. 
From the sixth decile upwards, people spend a greater share on other daily necessities than the lowest decile, while the spending behaviour of the second- to fifth deciles does not differ significantly from that of the lowest decile.

More educated people spend a smaller share on food and healthcare, but a greater share on education and leisure and transport and communications. This pattern may be related to preferences of such people for their children to have better education and to be more cautious in spending on food or healthcare. Older people spend more on healthcare and food and less on transport and communication and other daily necessities. A higher old-age ratio also makes families spend a greater share of their consumption spending on healthcare, though a smaller share on food and transport and communications. Families with more children and youth direct a greater share of their consumption to education and leisure and the coefficients are relatively large. More children and youth are associated with lower spending shares in almost all other categories.

The coefficient for the urban dummy is negative in the healthcare, education and leisure, transport and communications and other daily necessities equations, indicating that urban residence has an impact beyond spending capacity on how much of their consumption households direct to those categories. That is, urbanites spend a lower share on healthcare, for instance, not only because they earn more, but also because they have better health insurance. Migrants spend a smaller share on healthcare and education and leisure but a greater share on food than rural residents.

Table 7. Determinants of spending habit by decile, 2010-14

\begin{tabular}{|c|c|c|c|c|c|}
\hline $\begin{array}{l}\text { As a share of total } \\
\text { consumption expenditure }\end{array}$ & Food & Healthcare & $\begin{array}{l}\text { Education } \\
\text { and leisure }\end{array}$ & $\begin{array}{l}\text { Transport and } \\
\text { communication }\end{array}$ & $\begin{array}{l}\text { Other daily } \\
\text { expenses }\end{array}$ \\
\hline \multicolumn{6}{|l|}{ Consumption decile } \\
\hline 2 & $0.03^{* * *}$ & -0.01 & $0.01^{* * *}$ & $-0.01 * * *$ & 0.00 \\
\hline 3 & $0.03^{* * *}$ & -0.01 & $0.02^{* * *}$ & $-0.01 * * *$ & 0.00 \\
\hline 4 & $0.03^{* \star *}$ & -0.01 & $0.03^{* * *}$ & $-0.02 * * \star$ & 0.00 \\
\hline 5 & $0.03^{* * *}$ & $-0.01 *$ & $0.03^{* * *}$ & -0.02 *** & 0.00 \\
\hline 6 & $0.02^{* * *}$ & -0.01 & $0.04^{* * *}$ & $-0.02 * * *$ & 0.01 * \\
\hline 7 & $0.02 *$ & -0.01 & $0.04^{* * *}$ & -0.02 *** & $0.01 * *$ \\
\hline 8 & 0.01 & 0.00 & $0.03^{* * *}$ & $-0.03^{* * *}$ & $0.02^{* * *}$ \\
\hline 9 & -0.01 & 0.02 * & $0.03^{* * *}$ & $-0.03 * * *$ & $0.03^{* * *}$ \\
\hline 10 & $-0.11^{* * *}$ & $0.03^{* * *}$ & $0.02^{* * *}$ & $-0.03^{* * *}$ & $0.09 * * *$ \\
\hline \multicolumn{6}{|l|}{ Status } \\
\hline Migrant & $0.02^{* * *}$ & $-0.02^{* * *}$ & $-0.01^{* * *}$ & 0.00 & 0.00 \\
\hline Urban & $0.07^{* \star *}$ & $-0.03^{* * *}$ & $-0.02 * * *$ & $-0.01 *$ & $-0.02 * * \star$ \\
\hline Child ratio & 0.02 & $-0.03^{* * *}$ & $0.19^{* * *}$ & $-0.08^{* * *}$ & $-0.03^{* * *}$ \\
\hline Youth ratio & -0.06 ** & $-0.04^{* * *}$ & $0.21^{* * *}$ & $-0.03^{* * *}$ & $-0.04^{* * *}$ \\
\hline Olds ratio & $-0.01 *$ & $0.05^{* * *}$ & -0.01 & -0.02 *** & -0.00 \\
\hline Age & $0.00^{* * *}$ & $0.00^{\star \star \star}$ & 0.00 & $-0.00^{* * *}$ & $-0.00^{* * *}$ \\
\hline Education & $-0.01 * * *$ & $-0.01^{* * *}$ & $0.01^{* * *}$ & 0.00 *** & 0.00 \\
\hline \multicolumn{6}{|l|}{ Dummies year } \\
\hline 2012 & $0.03^{* * *}$ & $-0.03^{* * *}$ & $-0.01^{* * *}$ & $-0.03^{* * *}$ & $-0.01 *$ \\
\hline 2014 & $-0.02 *$ & $-0.03^{* * *}$ & -0.01 & $-0.02 * * *$ & $-0.01^{* * *}$ \\
\hline Constant & $0.38^{* * *}$ & $0.16^{* * *}$ & $-0.07^{* * *}$ & $0.19^{* * *}$ & $0.15^{* * *}$ \\
\hline $\mathrm{R} 2$ & 0.08 & 0.09 & 0.13 & 0.07 & 0.05 \\
\hline Observations & 25,922 & 25,922 & 25,922 & 25,922 & 25,922 \\
\hline
\end{tabular}

Note: Income, consumption and assets are in logarithms and on a per capita basis. OLS is used with year and residential status dummies with robust standard errors clustered at the province level. * indicate $p$ values, * significance at the $10 \%,{ }^{* *}$ at the $5 \%$ and ${ }^{* \star *}$ at the $1 \%$ level. A household is considered urban if the majority of its members reside in cities and have urban (non-agricultural) hukou, migrant if the majority of the family members reside in cities but have rural (agricultural) hukou and rural if the majority of the members reside in rural areas with a rural (agricultural) hukou.

Source: OECD estimations using the China Family Panel Studies database. 


\section{Wrapping up - inference from micro-data analysis points towards further rebalancing}

This paper investigated the impact of urbanisation on consumption, i.e. migrating to cities for work by rural households and obtaining an urban hukou by migrants who already reside in cities. While representativeness of migrants in the dataset may be an issue, the observed increase in consumption as a result of "upgrading" the hukou status suggests that the large-scale planned move of people up the residential ladder will likely result in increased consumption and thus contribute to rebalancing the economy. Cross-section analysis also showed that a higher residential status is associated with greater consumption. A simple back-of-the-envelope calculation - using the shares of urban-migrant-rural households in 2014 and the obtained coefficients capturing the impact of moving up the "residential ladder" - shows that the planned urbanisation move would boost overall household consumption by close to $11 \%$. Rural people's move to cities would contribute by over $3 \%$, while the change of residential status for migrant workers to urban hukou would account for the greater part, nearly $8 \%$. This highlights the importance of granting equal rights for migrant workers in cities in driving overall consumption and rebalancing the economy.

The major results of the analysis are summarised in Table 8. Increased income and longer time in education, which are part of the "upgrading" package, will contribute to rebalancing, but a higher share of children in the family discourages consumption likely owing to the need to save for their education. The analysis also confirmed the spending burden of education that children, in particular between the ages of 16 and 25, impose on the family. Furthermore, urban lifestyles will bring about a change in consumption patterns, not only because urbanites have higher spending capacity but also because they enjoy greater social security benefits and access to higher quality public services.

Table 8. Summary of results, 2010-14

\begin{tabular}{|l|c|c|c|c|c|c|c|}
\hline & & & \multicolumn{5}{|c|}{ Consumption of: } \\
\cline { 5 - 8 } & $\begin{array}{c}\text { Change in } \\
\text { consumption }\end{array}$ & Consumption & Food & Healthcare & $\begin{array}{c}\text { Education } \\
\text { and } \\
\text { leisure }\end{array}$ & $\begin{array}{c}\text { Transport } \\
\text { and } \\
\text { communi } \\
\text { cation }\end{array}$ & $\begin{array}{c}\text { Daily } \\
\text { expenses }\end{array}$ \\
\hline Rural-migrant & $0.28 * * *$ & & & & & \\
Migrant-urban & $0.27 * * *$ & & & & & & \\
Urban-migrant & $0.32 * * *$ & & & & & & \\
Status & & & & & & & \\
$\quad$ Migrant & & $0.24 * * *$ & $0.01 * *$ & $-0.01 * * *$ & $-0.01 * *$ & $-0.00 *$ & 0.00 \\
$\quad$ Urban & & $0.50 * * *$ & $0.05 * * *$ & $-0.02 * * *$ & $-0.01 * * *$ & $-0.01 * * *$ & $-0.01 * *$ \\
Kids ratio & & $-0.18 * * *$ & 0.03 & $-0.04 * * *$ & $0.18 * * *$ & $-0.08 * * *$ & $-0.04 * * *$ \\
Teens ratio & & $-0.12 * *$ & $-0.05 *$ & $-0.04 * * *$ & $0.22 * * *$ & $-0.03 * * *$ & $-0.05 * * *$ \\
Olds ratio & & 0.01 & $-0.02 * *$ & $0.05 * * *$ & -0.01 & $-0.02 * * *$ & -0.00 \\
Age & & 0.00 & $0.00 * * *$ & $0.00 * * *$ & 0.00 & $-0.00 * * *$ & $-0.00 * * *$ \\
Education & & $0.06 * * *$ & $-0.01 * * *$ & $-0.01 * * *$ & $0.01 * * *$ & $0.00 * * *$ & $0.00 * * *$ \\
\hline
\end{tabular}

Note: Consumption, age and education are expressed as household per capita averages, change in consumption is in log differences, consumption and its sub-components are in logarithms. A household is considered urban if the majority of its members reside in cities and have urban (non-agricultural) hukou, migrant if the majority of the family members reside in cities but have rural (agricultural) hukou and rural if the majority of the members reside in rural areas with a rural (agricultural) hukou.

Source: OECD estimations using the China Family Panel Studies database. 


\section{REFERENCES}

Cheung, D. and Y. Padieu (2014), "Heterogeneity of the effects of health insurance on household savings: Evidence from rural China", World Development, Vol. (66).

Croll, E. (2006), China's New Consumers: Social Development and Domestic Demand, Routledge Publishing.

Dreger, C., T. Wang and Y. Zhang (2013), "Understanding Chinese consumption: The impact of hukou", IZA Discussion Paper Series, No. 7819.

Gale, F. and K. Huang (2007), "Demand for food quantity and quality in China", United States Department of Agriculture Economic Research Report, No. 32.

Nicklaus, C. (2015) "The effect of household income on household consumption in China - The limited consumption potential of Chinese households", Master thesis, School of Economics and Management, Lund University, available at http://lup.lub.lu.se/luur/download?func=downloadFile\&recordOId=7374177\&fileOId=7374180 accessed on August 3, 2017.

OECD (2015), OECD Economic Surveys: China, OECD Publishing, Paris.

OECD (2017), OECD Economic Surveys: China, OECD Publishing, Paris.

Shen, Y. and X. Lei (2012), "2010 nian shouru xiaofei zhichu shuju zhengli” in Chinese (Sorting 2010 income and consumption spending data), China Family Panel Studies Technical Paper Series CFPS-15.

Westmore, B. (2017), "Do government transfers reduce poverty in China? Micro evidence from five regions", OECD Economics Department Working Papers, forthcoming.

Xie, Y. and J. Hu (2014), "An introduction to the China Family Panel Studies", Chinese Sociological Review, Vol. 47(1).

Xie, Y. and Y. Jin (2015), "Household wealth in China", Chinese Sociological Review, Vol. 47(3).

Xie, Y., X. Zhang, J. Li, X. Yu and Q. Ren (2014), Zhongguo Minsheng Fazhan Baogao 2014, in Chinese (Family Panel Data Studies 2014), Peking University Press, Beijing.

Xie, Y., X. Zhang, J. Li, P. Yu and Q. Ren (2016), Zhongguo Minsheng Fazhan Baogao 2016, in Chinese (Family Panel Data Studies 2016), Peking University Press, Beijing.

Zhou, Z., Y. Su, J. Gao, L. Xu and Y. Zhang (2011), "New estimates of elasticity of demand for healthcare in rural China", Health Policy Vol. 103. 
Table A.1. Consumption patterns of households by decile, 2010

CNY in current prices unless otherwise indicated

\begin{tabular}{|c|c|c|c|c|c|c|c|c|c|c|c|}
\hline Deciles (2010) & 1 & 2 & 3 & 4 & 5 & 6 & 7 & 8 & 9 & 10 & Total \\
\hline Income & 3,038 & 4,099 & 4,637 & 5,075 & 6,127 & 7,398 & 8,673 & 11,403 & 14,267 & 25,669 & 9,035 \\
\hline Consumption expenditure & 1,073 & 1,976 & 2,678 & 3,401 & 4,228 & 5,208 & 6,429 & 8,189 & 11,108 & 23,207 & 6,746 \\
\hline Assets & 26,322 & 36,763 & 31,392 & 34,312 & 43,779 & 52,020 & 70,669 & 99,277 & 164,812 & 283,792 & 84,277 \\
\hline \multicolumn{12}{|l|}{ Consumption by items: } \\
\hline Food & 516 & 920 & 1,187 & 1,495 & 1,810 & 2,170 & 2,516 & 3,192 & 4,296 & 6,542 & 2,464 \\
\hline Healthcare & 146 & 275 & 360 & 457 & 569 & 649 & 814 & 1,012 & 1,479 & 3,949 & 970 \\
\hline Clothing & 61 & 103 & 136 & 149 & 193 & 222 & 293 & 374 & 492 & 999 & 302 \\
\hline Other daily expenses & 107 & 200 & 280 & 340 & 459 & 513 & 694 & 900 & 1,171 & 3,081 & 774 \\
\hline Transport and communications & 114 & 224 & 312 & 401 & 515 & 629 & 746 & 944 & 1,297 & 2,910 & 809 \\
\hline Education and leisure & 69 & 146 & 229 & 338 & 399 & 662 & 833 & 1,074 & 1,426 & 2,722 & 789 \\
\hline Other & 17 & 32 & 45 & 64 & 66 & 102 & 153 & 196 & 237 & 1,226 & 214 \\
\hline $\begin{array}{l}\text { Family size (number of } \\
\text { persons) }\end{array}$ & 4.9 & 4.5 & 4.4 & 4.2 & 4.1 & 3.9 & 3.7 & 3.4 & 3.2 & 2.9 & 3.9 \\
\hline Age (years) & 38.2 & 37.3 & 37.0 & 38.6 & 38.6 & 39.7 & 39.4 & 40.7 & 42.8 & 43.6 & 39.6 \\
\hline Years in education & 5.8 & 6.3 & 6.7 & 6.7 & 7.0 & 7.4 & 7.8 & 8.4 & 9.1 & 9.9 & 7.5 \\
\hline Youth ratio (16-25 / hhd size) & 0.13 & 0.14 & 0.14 & 0.13 & 0.14 & 0.16 & 0.15 & 0.13 & 0.13 & 0.12 & 0.14 \\
\hline Old ratio (>64 / hhd size) & 0.14 & 0.10 & 0.09 & 0.11 & 0.10 & 0.11 & 0.10 & 0.11 & 0.13 & 0.15 & 0.11 \\
\hline \multicolumn{12}{|l|}{ Share of consumption: } \\
\hline Food & 48.1 & 46.5 & 44.3 & 44.0 & 42.8 & 41.7 & 39.1 & 39.0 & 38.7 & 28.2 & 36.5 \\
\hline Healthcare & 13.6 & 13.9 & 13.5 & 13.4 & 13.5 & 12.5 & 12.7 & 12.4 & 13.3 & 17.0 & 14.4 \\
\hline Clothing & 5.7 & 5.2 & 5.1 & 4.4 & 4.6 & 4.3 & 4.6 & 4.6 & 4.4 & 4.3 & 4.5 \\
\hline Housing & 4.1 & 3.9 & 4.8 & 4.6 & 5.2 & 5.0 & 5.9 & 6.1 & 6.4 & 7.7 & 6.3 \\
\hline Other daily expenses & 9.9 & 10.1 & 10.4 & 10.0 & 10.9 & 9.8 & 10.8 & 11.0 & 10.5 & 13.3 & 11.5 \\
\hline Transport and communications & 10.6 & 11.3 & 11.7 & 11.8 & 12.2 & 12.1 & 11.6 & 11.5 & 11.7 & 12.5 & 12.0 \\
\hline Education and leisure & 6.4 & 7.4 & 8.5 & 9.9 & 9.4 & 12.7 & 13.0 & 13.1 & 12.8 & 11.7 & 11.7 \\
\hline Other & 1.5 & 1.6 & 1.7 & 1.9 & 1.6 & 2.0 & 2.4 & 2.4 & 2.1 & 5.3 & 3.2 \\
\hline
\end{tabular}

Note: Deciles are defined for consumption.

Source: OECD calculations using the China Family Panel Studies database. 
Table A.2. Consumption patterns of households by decile, 2012

$\mathrm{CNY}$ in current prices unless otherwise indicated

\begin{tabular}{|c|c|c|c|c|c|c|c|c|c|c|c|}
\hline Deciles (2012) & 1 & 2 & 3 & 4 & 5 & 6 & 7 & 8 & 9 & 10 & Total \\
\hline Income & 6,278 & 6,715 & 7,105 & 7,614 & 8,876 & 9,036 & 10,831 & 13,093 & 17,935 & 26,093 & 11,358 \\
\hline Consumption expenditure & 1,546 & 2,854 & 3,968 & 5,063 & 6,276 & 7,713 & 9,518 & 12,109 & 16,645 & 36,002 & 10,169 \\
\hline Assets & 29,603 & 36,847 & 46,020 & 52,752 & 60,865 & 72,029 & 96,014 & 127,469 & 187,226 & 331,672 & 104,050 \\
\hline \multicolumn{12}{|l|}{ Consumption by items: } \\
\hline Food & 631 & 1,316 & 1,824 & 2,380 & 2,929 & 3,661 & 4,482 & 5,730 & 7,406 & 9,888 & 4,025 \\
\hline Healthcare & 210 & 328 & 435 & 557 & 656 & 792 & 896 & 1,262 & 1,782 & 3,603 & 1,052 \\
\hline Clothing & 120 & 190 & 252 & 291 & 359 & 419 & 462 & 620 & 808 & 1,678 & 520 \\
\hline Housing & 177 & 265 & 346 & 408 & 469 & 574 & 702 & 907 & 1,131 & 1,546 & 653 \\
\hline Other daily expenses & 120 & 213 & 310 & 423 & 522 & 620 & 810 & 1,065 & 1,736 & 10,595 & 1,641 \\
\hline Transport and communication & 167 & 263 & 371 & 428 & 524 & 629 & 838 & 987 & 1,363 & 2,656 & 823 \\
\hline Education and leisure & 93 & 210 & 321 & 425 & 614 & 757 & 965 & 1,077 & 1,607 & 3,507 & 958 \\
\hline Other & 28 & 68 & 108 & 152 & 203 & 261 & 362 & 463 & 813 & 2,529 & 499 \\
\hline $\begin{array}{l}\text { Family size (number of } \\
\text { persons) }\end{array}$ & 5.0 & 4.7 & 4.5 & 4.5 & 4.2 & 3.9 & 3.8 & 3.5 & 3.3 & 3.2 & 4.1 \\
\hline Age (years) & 41.4 & 39.9 & 40.7 & 40.2 & 40.3 & 41.0 & 41.7 & 42.8 & 43.9 & 42.5 & 41.4 \\
\hline Years in education & 6.7 & 6.8 & 7.2 & 7.4 & 7.7 & 8.0 & 8.4 & 8.9 & 9.2 & 10.2 & 8.0 \\
\hline Child ratio (<16 / hhd size) & 0.14 & 0.16 & 0.13 & 0.13 & 0.14 & 0.12 & 0.11 & 0.09 & 0.09 & 0.09 & 0.12 \\
\hline Youth ratio (16-25 / hhd size) & 0.13 & 0.13 & 0.13 & 0.13 & 0.13 & 0.14 & 0.13 & 0.14 & 0.12 & 0.11 & 0.13 \\
\hline Old ratio (>64 / hhd size) & 0.16 & 0.14 & 0.12 & 0.12 & 0.12 & 0.13 & 0.13 & 0.14 & 0.15 & 0.13 & 0.13 \\
\hline \multicolumn{12}{|l|}{ Share of consumption: } \\
\hline Food & 40.8 & 46.1 & 46.0 & 47.0 & 46.7 & 47.5 & 47.1 & 47.3 & 44.5 & 27.5 & 39.6 \\
\hline Healthcare & 13.6 & 11.5 & 11.0 & 11.0 & 10.5 & 10.3 & 9.4 & 10.4 & 10.7 & 10.0 & 10.3 \\
\hline Clothing & 7.7 & 6.7 & 6.3 & 5.7 & 5.7 & 5.4 & 4.9 & 5.1 & 4.9 & 4.7 & 5.1 \\
\hline Housing & 11.5 & 9.3 & 8.7 & 8.1 & 7.5 & 7.4 & 7.4 & 7.5 & 6.8 & 4.3 & 6.4 \\
\hline Other daily expenses & 7.7 & 7.5 & 7.8 & 8.4 & 8.3 & 8.0 & 8.5 & 8.8 & 10.4 & 29.4 & 16.1 \\
\hline Transport and communication & 10.8 & 9.2 & 9.4 & 8.4 & 8.4 & 8.2 & 8.8 & 8.1 & 8.2 & 7.4 & 8.1 \\
\hline Education and leisure & 6.0 & 7.4 & 8.1 & 8.4 & 9.8 & 9.8 & 10.1 & 8.9 & 9.7 & 9.7 & 9.4 \\
\hline Other & 1.8 & 2.4 & 2.7 & 3.0 & 3.2 & 3.4 & 3.8 & 3.8 & 4.9 & 7.0 & 4.9 \\
\hline
\end{tabular}

Note: Deciles are defined for consumption.

Source: OECD calculations using the China Family Panel Studies database. 
Table A.3. Determinants of spending by category, 2010

\begin{tabular}{|c|c|c|c|c|c|}
\hline $\begin{array}{l}\text { As a share of total } \\
\text { consumption } \\
\text { expenditure }\end{array}$ & Food & Healthcare & $\begin{array}{l}\text { Education and } \\
\text { leisure }\end{array}$ & $\begin{array}{l}\text { Transport and } \\
\text { communication }\end{array}$ & $\begin{array}{c}\text { Other daily } \\
\text { expenses }\end{array}$ \\
\hline \multicolumn{6}{|l|}{ Status } \\
\hline Migrant & 0.01 & $-0.01^{* *}$ & -0.01 & 0.00 & 0.00 \\
\hline Urban & $0.04^{* * *}$ & $-0.02^{* *}$ & $-0.03 * * *$ & $-0.01^{* *}$ & 0.00 \\
\hline Child ratio & $0.18^{* * *}$ & -0.02 & 0.03 * & $-0.10 * * *$ & $-0.03 *$ \\
\hline Youth ratio & -0.03 & $-0.05^{* *}$ & $0.21^{* \star *}$ & $-0.05^{* * *}$ & $-0.05^{* * *}$ \\
\hline Olds ratio & $-0.04 * *$ & $0.04 * *$ & 0.01 & $-0.01 * * *$ & 0.00 \\
\hline Age & $0.00^{* * *}$ & $0.00^{* * *}$ & $-0.00 * * *$ & $-0.00^{* * *}$ & $-0.00^{* * *}$ \\
\hline Education & $-0.01^{* * *}$ & $-0.01^{* * *}$ & $0.02^{* * *}$ & $0.00^{* * *}$ & $0.00^{* * *}$ \\
\hline \multicolumn{6}{|l|}{ Dummies year } \\
\hline \multicolumn{6}{|l|}{2012} \\
\hline \multicolumn{6}{|l|}{2014} \\
\hline Constant & $0.35^{\star \star \star}$ & $0.16^{* \star *}$ & 0.00 & $0.20^{* * *}$ & $0.13^{* * *}$ \\
\hline $\mathrm{R} 2$ & 0.07 & 0.07 & 0.14 & 0.04 & 0.01 \\
\hline Observations & 8,348 & 8,348 & 8,348 & 8,348 & 8,348 \\
\hline
\end{tabular}

Note: Consumption is in logarithms and on a per capita basis. OLS is used with year and residential status dummies with robust standard errors clustered at the province level. * indicate p values, ${ }^{*}$ significance at the $10 \%$, ${ }^{* *}$ at the $5 \%$ and ${ }^{* * *}$ at the $1 \%$ level. A household is considered urban if the majority of its members reside in cities and have urban (non-agricultural) hukou, migrant if the majority of the family members reside in cities but have rural (agricultural) hukou and rural if the majority of the members reside in rural areas with a rural (agricultural) hukou.

Source: OECD estimations using the China Family Panel Studies database.

Table A.4. Determinants of spending by category, 2012

\begin{tabular}{|c|c|c|c|c|c|}
\hline $\begin{array}{l}\text { As a share of total } \\
\text { consumption } \\
\text { expenditure }\end{array}$ & Food & Healthcare & $\begin{array}{l}\text { Education and } \\
\text { leisure }\end{array}$ & $\begin{array}{l}\text { Transport and } \\
\text { communication }\end{array}$ & $\begin{array}{l}\text { Other daily } \\
\text { expenses }\end{array}$ \\
\hline \multicolumn{6}{|l|}{ Status } \\
\hline Migrant & -0.01 & $-0.01^{* *}$ & 0.00 & 0.00 & 0.00 \\
\hline Urban & 0.00 & $-0.02 * *$ & 0.00 & 0.00 & $-0.01 * *$ \\
\hline Child ratio & -0.06 & $-0.05^{* * *}$ & $0.25^{* * *}$ & $-0.07 * * *$ & -0.04 \\
\hline Youth ratio & $-0.08 * * *$ & $-0.03 *$ & $0.23^{* * *}$ & $-0.03^{* *}$ & $-0.04^{* * *}$ \\
\hline Olds ratio & $-0.03 * *$ & $0.06^{* * *}$ & -0.01 & $-0.01^{\star * *}$ & -0.00 \\
\hline Age & 0.00 & 0.00 ** & 0.00 ** & $-0.00 * * *$ & $-0.00 * * *$ \\
\hline Education & -0.02 *** & $-0.01^{* * *}$ & $0.01^{* * *}$ & $0.00^{* * *}$ & $0.01 * * *$ \\
\hline \multicolumn{6}{|l|}{ Dummies year } \\
\hline \multicolumn{6}{|l|}{2012} \\
\hline \multicolumn{6}{|l|}{2014} \\
\hline Constant & $0.55^{* * *}$ & $0.12^{* * *}$ & $-0.11^{* * *}$ & $0.14^{* * *}$ & $0.12^{* * *}$ \\
\hline $\mathrm{R} 2$ & 0.05 & 0.07 & 0.14 & 0.04 & 0.02 \\
\hline Observations & 8,522 & 8,522 & 8,522 & 8,522 & 8,522 \\
\hline
\end{tabular}

Note: Consumption is in logarithms and on a per capita basis. OLS is used with year and residential status dummies with robust standard errors clustered at the province level. * indicate p values, ${ }^{*}$ significance at the $10 \%,{ }^{* *}$ at the $5 \%$ and ${ }^{* * *}$ at the $1 \%$ level. A household is considered urban if the majority of its members reside in cities and have urban (non-agricultural) hukou, migrant if the majority of the family members reside in cities but have rural (agricultural) hukou and rural if the majority of the members reside in rural areas with a rural (agricultural) hukou.

Source: OECD estimations using the China Family Panel Studies database. 
Table A.5. Determinants of spending by category, 2014

\begin{tabular}{|l|ccccc|}
\hline $\begin{array}{l}\text { As a share of total } \\
\text { consumption } \\
\text { expenditure }\end{array}$ & Food & Healthcare & $\begin{array}{c}\text { Education } \\
\text { and leisure }\end{array}$ & $\begin{array}{c}\text { Transport and } \\
\text { communication }\end{array}$ & $\begin{array}{c}\text { Other } \\
\text { daily } \\
\text { expenses }\end{array}$ \\
\hline Status & $0.05^{* * *}$ & $-0.02^{* * *}$ & $-0.01^{* * *}$ & $-0.02^{* * *}$ & 0.00 \\
$\quad$ Migrant & $0.11^{* * *}$ & $-0.03^{* * *}$ & $-0.01^{* *}$ & $-0.03^{* * *}$ & $-0.02^{* * *}$ \\
$\quad \begin{array}{l}\text { Urban } \\
\text { Child ratio }\end{array}$ & $-0.01^{* *}$ & $-0.03^{* *}$ & $0.27^{* * *}$ & $-0.09^{* * *}$ & $-0.04^{* *}$ \\
Youth ratio & -0.02 & $-0.04^{* * *}$ & $0.18^{* * *}$ & $-0.03^{* * *}$ & $-0.05^{* * *}$ \\
Olds ratio & $0.01^{* * *}$ & $0.06^{* * *}$ & $-0.01^{* * *}$ & $-0.03^{* * *}$ & -0.00 \\
Age & $0.00^{* *}$ & $0.00^{* * *}$ & $0.00^{* * *}$ & $-0.00^{* * *}$ & $-0.00^{* * *}$ \\
Education & $-0.01^{* * *}$ & $-0.01^{* * *}$ & $0.01^{* * *}$ & -0.00 & $0.00^{* * *}$ \\
Dummies year & & & & & \\
$\quad 2012$ & & & & & \\
$\quad 2014$ & & & & & \\
Constant & $0.35^{* * *}$ & $0.11^{* * *}$ & $-0.04^{* * *}$ & $0.18^{* * *}$ & $0.14^{* * *}$ \\
\hline R2 & 0.06 & 0.09 & 0.11 & 0.07 & 0.02 \\
Observations & 9,052 & 9,052 & 9,052 & 9,052 & 9,052 \\
\hline
\end{tabular}

Note: Consumption is in logarithms and on a per capita basis. OLS is used with year and residential status dummies with robust standard errors clustered at the province level. * indicate p values, ${ }^{*}$ significance at the $10 \%$, ${ }^{* *}$ at the $5 \%$ and ${ }^{* * *}$ at the $1 \%$ level. A household is considered urban if the majority of its members reside in cities and have urban (non-agricultural) hukou, migrant if the majority of the family members reside in cities but have rural (agricultural) hukou and rural if the majority of the members reside in rural areas with a rural (agricultural) hukou.

Source: OECD estimations using the China Family Panel Studies database. 
Table A.6. Determinants of spending shares by decile, 2010

\begin{tabular}{|c|c|c|c|c|c|}
\hline $\begin{array}{l}\text { As a share of total } \\
\text { consumption expenditure }\end{array}$ & Food & Healthcare & $\begin{array}{l}\text { Education } \\
\text { and leisure }\end{array}$ & $\begin{array}{l}\text { Transport and } \\
\text { communication }\end{array}$ & $\begin{array}{l}\text { Other daily } \\
\text { expenses }\end{array}$ \\
\hline \multicolumn{6}{|l|}{ Consumption decile } \\
\hline 2 & 0.01 & 0.01 & 0.00 & 0.00 & -0.01 \\
\hline 3 & -0.01 & 0.01 & 0.01 ** & 0.00 & 0.00 \\
\hline 4 & -0.02 & 0.01 & $0.03^{* * *}$ & 0.01 & -0.01 \\
\hline 5 & -0.03 & 0.02 & $0.02 * * *$ & 0.01 & 0.00 \\
\hline 6 & -0.04 * & 0.01 & $0.05^{* * *}$ & 0.01 & $-0.01^{\star *}$ \\
\hline 7 & $-0.07^{* * *}$ & 0.02 & $0.05^{* * *}$ & 0.00 & 0.00 \\
\hline 8 & $-0.08^{* * *}$ & 0.03 * & $0.05^{* * *}$ & 0.01 & 0.00 \\
\hline 9 & $-0.09 * * *$ & $0.05^{* *}$ & $0.05^{* * *}$ & 0.01 & -0.01 \\
\hline 10 & $-0.16^{\star * *}$ & $0.09 * * *$ & $0.03^{* * *}$ & 0.02 * & 0.01 \\
\hline \multicolumn{6}{|l|}{ Status } \\
\hline Migrant & 0.02 * & $-0.02 * * *$ & -0.01 ** & -0.00 & 0.00 \\
\hline Urban & $0.08^{* * *}$ & $-0.03^{* * *}$ & $-0.04^{* * *}$ & $-0.01^{* * *}$ & 0.00 \\
\hline Child ratio & $0.14^{* * *}$ & 0.00 & $0.05^{* *}$ & $-0.10^{* * *}$ & -0.03 \\
\hline Youth ratio & $-0.05^{*}$ & $-0.03 *$ & $0.21^{* * *}$ & $-0.05^{* * *}$ & $-0.04 * * *$ \\
\hline Olds ratio & -0.04 ** & 0.04 * & 0.01 ** & $-0.01^{* * *}$ & 0.00 \\
\hline Age & $0.00 * * *$ & $0.00 * * *$ & $-0.00 * * *$ & $-0.00 * * *$ & $-0.00^{* * *}$ \\
\hline Education & $-0.01^{* * *}$ & $-0.01^{* * *}$ & $0.01^{* * *}$ & 0.00 *** & $0.00 * * *$ \\
\hline \multicolumn{6}{|l|}{ Dummies year } \\
\hline \multicolumn{6}{|l|}{2012} \\
\hline \multicolumn{6}{|l|}{2014} \\
\hline Constant & 0.36 *** & $0.16^{* * *}$ & -0.02 & $0.20^{* * *}$ & $0.13^{* * *}$ \\
\hline $\mathrm{R} 2$ & 0.11 & 0.08 & 0.15 & 0.05 & 0.01 \\
\hline Observations & 8,348 & 8,348 & 8,348 & 8,348 & 8,348 \\
\hline
\end{tabular}

Note: Consumption is in logarithms and on a per capita basis. OLS is used with year and residential status dummies with robust standard errors clustered at the province level. * indicate p values, * significance at the $10 \%$, ${ }^{* *}$ at the $5 \%$ and ${ }^{* *}$ at the $1 \%$ level. A household is considered urban if the majority of its members reside in cities and have urban (non-agricultural) hukou, migrant if the majority of the family members reside in cities but have rural (agricultural) hukou and rural if the majority of the members reside in rural areas with a rural (agricultural) hukou.

Source: OECD estimations using the China Family Panel Studies database. 
Table A.7. Determinants of spending shares by decile, 2012

\begin{tabular}{|c|c|c|c|c|c|}
\hline $\begin{array}{l}\text { As a share of total } \\
\text { consumption expenditure }\end{array}$ & Food & Healthcare & $\begin{array}{l}\text { Education } \\
\text { and leisure }\end{array}$ & $\begin{array}{l}\text { Transport and } \\
\text { communication }\end{array}$ & $\begin{array}{l}\text { Other daily } \\
\text { expenses }\end{array}$ \\
\hline \multicolumn{6}{|l|}{ Consumption decile } \\
\hline 2 & $0.07^{* * *}$ & $-0.02 * *$ & 0.01 & $-0.02 * * *$ & -0.00 \\
\hline 3 & $0.08^{* * *}$ & $-0.02 * * *$ & $0.02^{* * *}$ & $-0.02 * * *$ & 0.00 \\
\hline 4 & $0.09 * * *$ & $-0.02^{* *}$ & $0.02 * * *$ & $-0.03^{* * *}$ & 0.01 \\
\hline 5 & $0.09 * * *$ & $-0.02 * * *$ & $0.03^{* * *}$ & $-0.04^{* * *}$ & 0.01 \\
\hline 6 & $0.10^{* * *}$ & $-0.02 * * \star$ & $0.03^{* * *}$ & $-0.04 * \star *$ & 0.01 \\
\hline 7 & $0.10^{* * *}$ & $-0.03^{* * *}$ & $0.03^{* * *}$ & $-0.04^{* * *}$ & 0.01 ** \\
\hline 8 & $0.11^{* * *}$ & $-0.02 * *$ & $0.01^{* * *}$ & $-0.04 * * *$ & 0.02 ** \\
\hline 9 & $0.08^{* * *}$ & -0.01 & 0.02 *** & $-0.04 * * *$ & $0.04^{* * *}$ \\
\hline 10 & -0.03 & 0.00 & 0.02 *** & $-0.05^{* * *}$ & $0.15^{* * *}$ \\
\hline \multicolumn{6}{|l|}{ Status } \\
\hline Migrant & -0.02 & -0.01 ** & 0.00 & 0.00 & -0.00 \\
\hline Urban & 0.01 & $-0.02 * *$ & -0.01 & 0.01 & $-0.04^{* * *}$ \\
\hline Child ratio & -0.07 & $-0.05^{* * *}$ & $0.25^{* * *}$ & $-0.07^{* * *}$ & -0.03 \\
\hline Youth ratio & $-0.09 * * *$ & -0.03 * & $0.24^{* * *}$ & $-0.03^{* * *}$ & $-0.03 * *$ \\
\hline Olds ratio & -0.03 ** & $0.06^{* * *}$ & -0.01 & $-0.02 * * *$ & -0.00 \\
\hline Age & 0.00 & 0.00 ** & 0.00 ** & $-0.00 * * *$ & $-0.00 * * *$ \\
\hline Education & $-0.01^{* * *}$ & $-0.01^{* * *}$ & $0.01^{* * *}$ & $0.00^{* * *}$ & $0.00^{*}$ \\
\hline \multicolumn{6}{|l|}{ Dummies year } \\
\hline \multicolumn{6}{|l|}{2012} \\
\hline \multicolumn{6}{|l|}{2014} \\
\hline Constant & $0.48^{* * *}$ & $0.14^{* * *}$ & $-0.12^{* \star *}$ & $0.16^{* * *}$ & $0.13^{* * *}$ \\
\hline $\mathrm{R} 2$ & 0.08 & 0.08 & 0.15 & 0.06 & 0.10 \\
\hline Observations & 8,522 & 8,522 & 8,522 & 8,522 & 8,522 \\
\hline
\end{tabular}

Note: Consumption is in logarithms and on a per capita basis. OLS is used with year and residential status dummies with robust standard errors clustered at the province level. * indicate p values, ${ }^{*}$ significance at the $10 \%$, ${ }^{* *}$ at the $5 \%$ and ${ }^{* * *}$ at the $1 \%$ level. A household is considered urban if the majority of its members reside in cities and have urban (non-agricultural) hukou, migrant if the majority of the family members reside in cities but have rural (agricultural) hukou and rural if the majority of the members reside in rural areas with a rural (agricultural) hukou.

Source: OECD estimations using the China Family Panel Studies database. 
Table A.8. Determinants of spending shares by decile, 2014

\begin{tabular}{|c|c|c|c|c|c|}
\hline $\begin{array}{l}\text { As a share of total } \\
\text { consumption expenditure }\end{array}$ & Food & Healthcare & $\begin{array}{c}\text { Education } \\
\text { and leisure }\end{array}$ & $\begin{array}{l}\text { Transport and } \\
\text { communication }\end{array}$ & $\begin{array}{l}\text { Other daily } \\
\text { expenses }\end{array}$ \\
\hline \multicolumn{6}{|l|}{ Consumption decile } \\
\hline 2 & $0.02^{* \star *}$ & -0.01 & $0.02^{* * *}$ & -0.01 ** & 0.00 \\
\hline 3 & 0.02 ** & -0.01 & $0.02^{* * *}$ & $-0.02^{* *}$ & 0.01 * \\
\hline 4 & 0.02 ** & -0.01 & $0.03^{* * *}$ & $-0.02 * * *$ & 0.00 \\
\hline 5 & $0.03^{* * *}$ & -0.02 *** & $0.03^{* * *}$ & $-0.03^{* * *}$ & 0.00 \\
\hline 6 & 0.01 & 0.00 & $0.04 * * *$ & $-0.03^{* * *}$ & $0.02 * * *$ \\
\hline 7 & 0.01 & -0.01 & 0.02 ** & $-0.03^{* * *}$ & 0.02 *** \\
\hline 8 & 0.00 & -0.01 & 0.02 ** & $-0.04^{* * *}$ & $0.03^{* * *}$ \\
\hline 9 & $-0.05^{* *}$ & $0.03^{*}$ & 0.01 ** & $-0.04^{* * *}$ & $0.04^{* * *}$ \\
\hline 10 & $-0.16^{* \star *}$ & 0.02 & 0.01 & -0.06 *** & $0.11^{* * *}$ \\
\hline \multicolumn{6}{|l|}{ Status } \\
\hline Migrant & $0.06^{* * *}$ & -0.02 *** & $-0.01 * * *$ & $-0.01 * * *$ & -0.00 \\
\hline Urban & $0.13^{* \star *}$ & $-0.04^{* * *}$ & $-0.01 * *$ & $-0.01 * * *$ & $-0.04^{* * *}$ \\
\hline Child ratio & -0.01 & $-0.04^{* *}$ & $0.26^{* * *}$ & $-0.09 * * *$ & $-0.04^{* *}$ \\
\hline Youth ratio & -0.02 & $-0.04^{* * *}$ & $0.18^{* * *}$ & $-0.03^{* * *}$ & $-0.05^{* * *}$ \\
\hline Olds ratio & 0.02 & $0.06^{* * *}$ & -0.01 & $-0.03^{* * *}$ & -0.01 \\
\hline Age & $0.00^{* *}$ & $0.00 * * *$ & $0.00 * * *$ & $-0.00 * * *$ & $-0.00 * * *$ \\
\hline Education & -0.00 & $-0.01 * * *$ & $0.01^{* * *}$ & 0.00 & -0.00 \\
\hline \multicolumn{6}{|l|}{ Dummies year } \\
\hline \multicolumn{6}{|l|}{2012} \\
\hline \multicolumn{6}{|l|}{2014} \\
\hline Constant & $0.31^{* * *}$ & $0.12^{* * *}$ & $-0.07^{* * *}$ & $0.19^{* * *}$ & $0.15^{* * *}$ \\
\hline $\mathrm{R} 2$ & 0.12 & 0.10 & 0.12 & 0.09 & 0.07 \\
\hline Observations & 9,052 & 9,052 & 9,052 & 9,052 & 9,052 \\
\hline
\end{tabular}

Note: Consumption is in logarithms and on a per capita basis. OLS is used with year and residential status dummies with robust standard errors clustered at the province level. ${ }^{*}$ indicate $\mathrm{p}$ values, ${ }^{*}$ significance at the $10 \%,{ }^{* *}$ at the $5 \%$ and ${ }^{* * *}$ at the $1 \%$ level. A household is considered urban if the majority of its members reside in cities and have urban (non-agricultural) hukou, migrant if the majority of the family members reside in cities but have rural (agricultural) hukou and rural if the majority of the members reside in rural areas with a rural (agricultural) hukou.

Source: OECD estimations using the China Family Panel Studies database. 